\title{
TEMBANG MACAPAT SEBAGAI SUMBER IDE GENDING-GENDING KARYA KI NARTOSABDO
}

\author{
Suparto $^{1}$
}

\begin{abstract}
Ki Nartasabda used Sekar Macapat as one of the inspirations in creating gamelan ensemble compositions. The expression of the Javanese traditional poetry was applied in the composition elements such as bawa, gerongan, and lelagon. Therefore, the elements were related to different ambiences of the traditional songs and cakepan did not completely follow the rimes of the Javanese poetry and also cengkok in the Sekar Macapat. The Sekar Macapat in the gamelan ensemble compositions created by Ki Nartasabda was expressed implicitly and explicitly in the bawa, the gerongan and the lelagon. The examples of the gamelan ensemble compositions were contained in the forms of Bawa Sekar Mijil, Ladrang Pocung, Lelagon Gambuh Pangatag, Lancaran Wira-wiri, and Lancaran Begadhang (Sinom).
\end{abstract}

Keywords: Macapat, Gending, Compositions

\section{Pendahuluan}

Seni karawitan merupakan salah satu seni di Jawa yang keberadaannya sampai sekarang masih sangat dibutuhkan oleh masyarakat baik sebagai sarana ritual maupun sebagai hiburan. Sebagai sarana untuk keperluan ritual seperti misalnya, untuk mengiringi lagu-lagu Ibadat Ekarisiti atau Misa di gereja-gereja Katolik dan sebagai hiburan di berbagai tempat hajatan antara lain; Upacara pernikahan (mantènan), khitanan (sunatan), iringan wayang (karawitan pakeliran) dan iringan tari (karawitan tari). Hal itu membuktikan bahwa karawitan memiliki toleransi yang cukup besar dengan budaya masyarakat dan mampu beradaptasi sesuai dengan perkembangan jaman.

Sajian seni karawitan berupa gending atau lagu, yaitu susunan nada dalam karawitan Jawa yang berupa instrumental dengan menggunakan laras slendro dan

\footnotetext{
${ }^{1}$ Dosen Jurusan Pedalangan FSP ISI Yogyakarta.
} 
pelog. ${ }^{2}$ Gending dapat ditampilkan dalam bentuk instrumentalia (gending yang ditampilkan dengan alat musik gamelan saja) dan ditampilkan dalam bentuk vokal (gending yang ditampilkan dengan tembang). Adapun vokal di dalam seni karawitan dapat berupa solo vokal maupun bentuk gérongan atau koor, sedangkan syairnya dapat berupa wangs $\underline{a} \underline{a}$ an purwa kanthi maupun Sêkar Agêng, Sêkar Têgahan, dan Macapạt.

Tembang secara genetik menunjukkan vokal lagu Jawa, yang dahulunya disebut dengan istilah kidung (nyanyian). ${ }^{3}$ Tembang dapat dibagi menjadi 3 bagian yaitu: (1) tembang Gêdhé, (2) tembang Tênga $\underline{a} \underline{a}$, dan (3) tembang Macapát. Istilah tembang dalam bahasa yang lebih halus (krama) disebut dengan kata sêkar, maka ketiga tembang tersebut menjadi kesatuan istilah Sêkar Agêng, Sêkar Têngahan dan Sêkar Macapạt.

Pada awalnya jenis tembang-tembang tersebut mempuyai fungsi sendiri-sendiri. Têmbang Gêdhé (Sêkar Agêng) dan Têmbang Têngahhan (Sêkar Têngahan) berfungsi untuk bawa swara (solo vokal sebagai pembuka gending atau buka), sedangkan Tembang Macapạt ( Sêkar Macapát) ditembangkan secara lepas (tanpa iringan musik gamelan) untuk acara-acara ritual seperti misalnya; Kidung Rahayu yang ditembangkan untuk memohon keselamatan dan dijauhkan dari semua marabahaya. Salah satu syairnya berbunyi sebagai berikut.

Ana kidung rumêksa ing wêngi, têguh hayu luputa ing lara, luputa bilahi kabèh, jim sétan da्atan purun, panêluhan tạn ana wani, miwah panggawé ala, gunané wong luput, gêni atêma han tirta, maling adoh tan ana ngarah mring kami, tuju duduk pan sirna (Anonim, tanpa tahun: 1).

Di samping itu Sêkar Macapat juga sering dilantumkan dalam acara wungon tirakatan bagi orang Jawa, pada waktu kelahiran bayi (bayènan) atau upacara jagong bayi di tempat orang yang baru saja melahirkan anak (jagongan bayèn). Diadakan nyanyian Macapat ini secara spiritual bertujuan agar si bayi yang baru lahir tersebut diberikan keselamatan dan kesehatan. Acara seperti ini bahkan ada yang dilaksanakan

\footnotetext{
2 Soetarno. Pertunjukan Wayang \& Makna Simbolisme, STSI Press. Surakarta, 2005, 84.

3 Subalidinata, R.S. Kawruh Kasustraan Jawa, Yayasan Pustaka Nusantara, Yogyakarta. 1994, 23.
} 
selama sêlapan (35 hari). Adapun yang ditembangkan biasanya diambil dari Sêrat Makukuhan, Sêrat Rama, Sêrat Ambya dan lain-lain.

Seiring dengan perkembangan jaman, Sêkar Macapat yang pada awalnya merupakan sarana ritual akhirnya muncul kesenian yang disebut Langên Mandrawanara di Keraton Kasultanan Yogyakarta dan Langêndriyan di Surakarta dengan menggunakan tembang tersebut sebagai pengganti dialog tokoh wayang yang keluar dalam setiap adegan. Lagu dan céngkok pada nyanyian kedua genre seni tersebut berbeda degan céngkok maupun lagu Macapat. Ragam tembang Macapát ada 11 macam, yaitu: (1) Mijil; (2) Maskumambang; (3) Sinom; (4) Asmarandana; (5) Kinanthi; (6) Gambuh; (7) Dhandhanggula; (8) Durma; (9) Pangkur; (10) Mêgatruh; dan (11) Pocung.

Sesuai dengan sifatnya yang tradisi maka tembang-tembang tersebut memiliki aturan yang sifatnya sangat mengikat misalnya; guru wilangan (jumlah suku kata dalam setiap baris), guru lagu (persajakan). Oleh karena yang akan dikaji dalam penelitian ini adalah bentuk Sêkar Macapat, maka di bawah sangat penting ditampilkan 11 macam

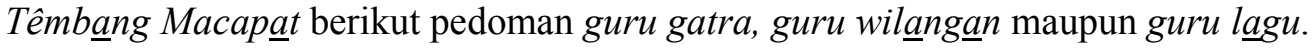

\begin{tabular}{|l|l|c|l|}
\hline No. & Jenis Tembang & $\begin{array}{l}\text { Jumlah gatra } \\
\text { (baris) tiap bait }\end{array}$ & $\begin{array}{l}\text { Guru wilangan (jumlah suku kata } \\
\text { tiap baris), guru lagu (persajakan) }\end{array}$ \\
\hline 1. & Mijil & 6 baris & $10-\mathrm{i}, 6-\mathrm{o}, 10-\mathrm{e}, 10-\mathrm{i}, 6-\mathrm{i}, 6-\mathrm{u}$ \\
\hline 2. & Maskumambang & 4 baris & $12-\mathrm{i}, 6-\mathrm{a}, 8-\mathrm{i}, 8-\mathrm{a}$ \\
\hline 3. & Sinom & 9 baris & $8-\mathrm{a}, 8-\mathrm{i}, 8-\mathrm{a}, 8-\mathrm{i}, 7-\mathrm{i}, 8-\mathrm{u}, 7-\mathrm{a}, 8-\mathrm{i}, 12-\mathrm{a}$ \\
\hline 4. & Asmarandana & 7 baris & $8-\mathrm{i}, 8-\mathrm{a}, 8-\mathrm{e} / \mathrm{o}, 8-\mathrm{a}, 7-\mathrm{a}, 8-\mathrm{u}, 8-\mathrm{a}$ \\
\hline 5. & Kinanthi & 6 baris & $8-\mathrm{u}, 8-\mathrm{i}, 8-\mathrm{a}, 8-\mathrm{i}, 8-\mathrm{a}, 8-\mathrm{o}$ \\
\hline 6. & Gambuh & 5 baris & $7-\mathrm{u}, 10-\mathrm{u}, 12-\mathrm{i}, 8-\mathrm{u}, 8-\mathrm{o}$ \\
\hline 7. & Dhandanggula & 10 baris & $\begin{array}{l}10-\mathrm{i}, 8-\mathrm{a}, 8-\mathrm{e}, 7-\mathrm{u}, 9-\mathrm{i}, 7-\mathrm{a}, 6-\mathrm{u}, 8-\mathrm{a}, \\
12-\mathrm{i}, 7-\mathrm{a}\end{array}$ \\
\hline 8. & Durma & 7 baris & $12-\mathrm{a}, 7-\mathrm{i}, 6-\mathrm{a}, 7-\mathrm{a}, 8-\mathrm{a}, 5-\mathrm{a}, 7-\mathrm{i}$ \\
\hline 9. & Pangkur & 7 baris & $8-\mathrm{a}, 11-\mathrm{i}, 8-\mathrm{u}, 7-\mathrm{a}, 12-\mathrm{a}, 8-\mathrm{a}, 8-\mathrm{i}$ \\
\hline 10. & Megatruh & 5 baris & $12-\mathrm{u}, 8-\mathrm{i}, 8-\mathrm{u}, 8-\mathrm{i}, 8-\mathrm{o}$ \\
\hline 11. & Pocung & 4 baris & $12-\mathrm{u}, 6-\mathrm{a}, 8-\mathrm{I}, 12-\mathrm{a}$ \\
\hline
\end{tabular}

Model sajian seni karawitan mengalami perkembangan, maka selain menyajikan karya empu-empu pada jaman dahulu juga disajikan gending-gending model, baru hasil gubahan dan ciptaan dari para empu masa selanjutnya. Sekitar tahun 70-an tumbuh dan berkembang gending-gending kreasi baru dalam berbagai garap (bentuk) yang berbeda dengan garap klasik seperti misalnya; bentuk langgam, dhangdhutan sampai dengan 
garap kontemporer. Pada dasa warsa itu muncul nama-nama komposer seperti antara lain; R. C Hardjo Subroto, Ki Wasito Dipuro, R. L Marto Pangrawit dan lain-lain. Menurut Waridi pada dasarnya karya karawitan yang ada sekarang ini terlahir dari gending-gending tradisi (klasik) Jawa, yang masih terkait dan menggunakan idiomidiom lama dan menggunakan pendekatan tradisi dan menginterpretasikan lagu dari tembang (Sêkar Macapạt, Sêkar Têngahan dan Lagu Dolanan $\underline{\text { Ana }} \underline{a}$ ). Demikian pula karya Ki Nartosabdo juga berpijak dari pendekatan tradisi semcam itu.

Kesekian banyak karya komposer yang ada pada waktu itu, karya Ki Nartosabdo dapat dikatakan paling kuat pengaruhnya. Hal ini dapat dibuktikan dengan seringnya disajikan gending-gending karya Ki Nartosabdo di berbagai tempat dengan cara melalui casset audio maupun di dalam pergelaran karawitan lepas (uyon-uyon) atau di dalam pertunjukan wayang orang panggung maupun wayang kulit purwa dan lain-lain. Karya Ki Nartosabdo sangat populer (dikenal dan disukai oleh masyarakat) terutama para pengrawit. Dengan demikian gending-gending karawitan model garapan Ki Nartosabdo dapat menjadi ikon masyarakat pada masa itu, bahkan sampai sekarang masih kuat keberadaannya.

Ki Nartosabdo yang nama kecilnya Sunarto lahir di Desa Pandes, Kecamatan Wedi, Kabupaten Klaten pada tanggal 25 Agustus 1925. Sebagai anak dari Partotinoyo adalah seorang empu keris dan juga seorang pengrawit tak mengherankan jika bakat seninya sudah tampak sejak masih kecil, sehingga pada usia 11 tahun ia sudah dapat menguasai seluruh instrumen gamelan. Sunarto kecil itu pernah sekolah di Standar School Muhammadiyah Klaten, sore harinya bersama Sumarsih kakak perempuannya kursus tari di Irabangsan Wedi Klaten dibawah asuhan R. M Suraji dari Surakarta. Oleh karena tidak bisa membayar uang sekolah akhirnya tidak dapat melanjutkan sekolah dan hanya sampai dengan kelas dua pada jenjang Sekolah Menengah Pertama.

Bakat seninya yang menonjol itu diketahui oleh Romo Harjo Suwondo seorang pengasuh sekolah Katolik, Sunarto disuruh sekolah di Yayasan Katolik tersebut tanpa dipungut biaya. Di sekolah itu ia mulai belajar melukis, memainkan gitar dan biola, dan menyanyi lagu-lagu keroncong. Setelah itu ia aktif sebagai anggota Wayang Orang Sri Cahya Mulya dan juga aktif sebagai pengrawit seorang dalang kondang yaitu Ki Pujosumarto dari Klaten pada tahun 1950an. 
Berkat pengalaman yang dimiliki akhirnya dapat membawa Sunarto sampai ke rombongan Wayang Orang Ngèsti Pandhawa pimpinan Ki Sastrosabdo, dan mengikuti pementasan dari kota ke kota yang lain. Di setiap kota dimana Wayang Orang Ngèsti Pandhawa mengadakan pementasan, ia selalu menyempatkan diri untuk dapat belajar karawitan di daerah tersebut, sehingga tak mengherankan apabila ia juga menguasai gaya karawitan daerah lain seperti Banyumasan, Pasundan, Banyuwangi dan lain-lain. Oleh karena Sunarto dianggap berjasa pada Ngèsti P $\underline{a}$ dhawa, maka pada tahun 1950 oleh pimpinan Ngèsti Pandhawa ia diberi anugerah gelar nama Sabdo, kemudian namanya diganti menjadi Nartosabdo.

Sejak saat itu ia mulai membuat karya-karya karawitan kreasi baru seperti ; Kêtáwang Ibu Pêrtiwi, Lagu Swara Suling, Lagu Práon dan lain sebagainya. Karyakaryanya sering kali ditampilkan pada pertunjukan wayang kulit purwa Gaya Yogyakarta maupun Surakarta terutama pada saat adegan Gara-Gara. Seiring dengan kepopuleran gending-gending kreasi baru karya Ki Nartosabdo tersebut muncul berbagai tanggapan baik yang bersifat positif maupun negatif. Di kalangan akademisi misalnya; menilai bahwa karya-karya Ki Nartosabdo kurang berbobot atau tidak mempertimbangkan aspek garap instrumen seperti; rêbab, gêndèr, dan bonang sehingga para pengrawit menemui kesulitan dalam menginterpretasikan garapnya, bahkan ada yang berpendapat gending-gending karya Ki Nartosabdo lebih bersifat komersial atau hanya ingin memenuhi selera pasar. Di sisi lain yakni masyarakat pada umumnya dalam menanggapi karya-karya $\mathrm{Ki}$ Nartosabdo berbeda dari kalangan akademik. Mereka menilai positif terhadap gending-gending karya Ki Nartosabdo tersebut dengan pertimbangan antara lain; lebih menarik dan banyak digemari masyarakat, lebih komunikatif; lagu maupun syairnya mudah dihafalkan dan lain-lain.

Gending-gending kreasi baru karya Ki Nartosabdo, ${ }^{4}$ garap musikalitas karawitan Jawanya dapat dibagi menjadi tiga jenis yaitu: (1) jenis karawitan yang masih menggunakan medium dan idiom lama, (2) jenis karawitan yang menggunakan medium lama tetapi dengan idiom baru, (3) jenis karawitan yang menggunakan medium baru dengan idiom baru pula. Sesuai dengan judul yang ditawarkan, apakah Nartosabdo menggunakan idiom-idiom tembang Macapat sebagai sumber ide pembuatan gending-

\footnotetext{
${ }^{4}$ Marsudi. "Ciri Khas Gendhing-gendhing Ki Nartosabdo Suatu Kajian Aspek Musikologi Karawitan " Tesis S-2 Program Pasca Sarjana, Universitas Gadjah Mada Yogyakarta, 1998, 4.
} 
gending karawitan? Untuk menjawab pertanyaan ini harus dilakukan dengan cara penelitian dengan objek gending-gending karya Ki Nartosabdo.

\section{Pembahasan}

Setelah dilakukan penelitian melalui gending-gending ciptaan Ki Nartasabdo ditemukan berbagai gending yang idenya diambil dari Sêkar Macapat, baik berupa bawa, gérongạn, dan sêkaran (lêlagon). Adapun bukti visualnya berupa notasi lagu dan cakêpan (syair) sebagai berikut.

A. Bawa.

Berbagai bawa yang menggunakan pedoman Macapat yaitu: (1) Bawa sêkar Mijil kátampèn lancaranan Gandrung Mangu, (2) bawa sêkar Gambuh kátampên lancaran Ayo Ngguyu, (3) bawa sêkar Kinanthi katampên lancaran Kan Kagok

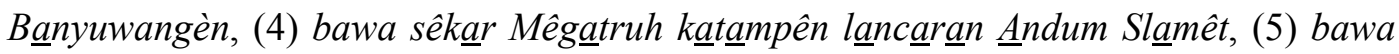
sêkar Pangkur kátampên lanccaran Éling-éling Banyumásan, (6) bawa sêkar Asmarandana kátämpên lancarạn Godril Banyumásan, (7) bawa sêkạr Sinom,

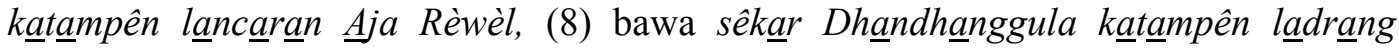
Bribil, dan (9) bawa sêkar Pocung katampên la adrang Pujimaya. Adapun secara visual gending-gending karya Ki Nartasabdo yang bawa-nya diambil dari Macapat sebagai berikut.

1. Bawa sêkar Mijil kâtampèn lancaran Gandrung Mangu.
Buka
: $6 \begin{array}{llll}6 & 1 & 2 & 3\end{array}$
$\begin{array}{llll}5 & 5 & 2 & 1\end{array}$
$\begin{array}{llll}3 & 2 & 1 & 6\end{array}$
G

A. Balungan Gending.

\begin{tabular}{|c|c|c|c|c|c|c|c|}
\hline $\mathrm{N}$ & $\mathrm{P}$ & $\mathrm{N}$ & $\mathrm{P}$ & $\mathrm{N}$ & $\mathrm{P}$ & $\mathrm{N}$ & \\
\hline 6 & 1 & 6 & . 2 & 3 & 5 & 6 & $\mathrm{G}$ \\
\hline 2 & 3 & 2 & 5 & 6 & 5 & 3 & $\mathrm{G}$ \\
\hline 1 & 2 & 3 & 5 & 3 & 2 & 1 & $\mathrm{G}$ \\
\hline 1 & 2 & 1 & 3 & 5 & 6 & 1 & $\mathrm{G}$ \\
\hline 1 & 2 & 3 & 2 & 1 & 2 & 6 & $\mathrm{G}-\mathrm{A} /$ suwuk \\
\hline
\end{tabular}

B. Buka Cêluk Bawa Sêkar Mijil

$$
\begin{aligned}
& \begin{array}{llllllllllll}
6 & 6 & \underline{61} & \underline{56} & 2 & \underline{3} & 5 & 3 & 3 & \underline{6} & 56 & 6
\end{array} \\
& \text { A-pa ri-ka gên-dhung tu - ru ma-ning }
\end{aligned}
$$


$2 \underline{3234216} \quad 3 \quad 3 \quad \underline{3} \quad 3 \quad \underline{23}$

U-rip - pê nggênté - yong

$\begin{array}{llllllllll}3 & 3 & 3 & \underline{63} & 2 & 1 & 2 & 1 & \underline{12} & \underline{2.1}\end{array}$

Ka-ya sok - $\underline{a}-n y i-\quad d r a$ da-du - wèk é

$\begin{array}{llllllllll}2 & 1 & 2 & 3 & 6 & 1 & 1 & 1 & 1 & \underline{16121}\end{array}$

Sê-nêng mangsa woh kangma-nis ma-nis

$\underline{123} \quad 1 \quad 6 \quad 5 \quad \underline{556} \quad \underline{5653}$

Yèn ri - na an - dhê lik

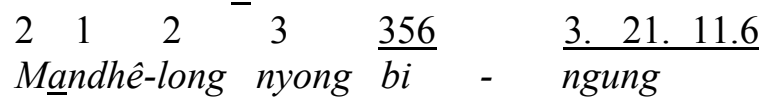

C. Lêlagon. ${ }^{5}$

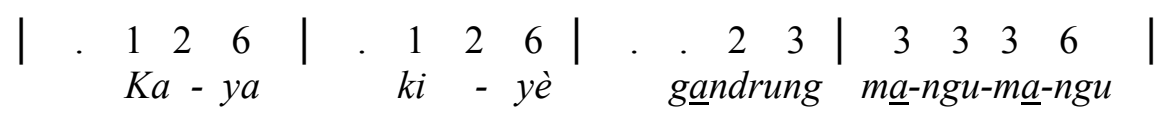

$$
\begin{aligned}
& \begin{array}{|llll|llll|llll|llll|}
\hline & . & 2 & 3 & 2 & 3 & 3 & 2 & 2 & . & 6 & 6 & 6 & 3 & 3 & 3
\end{array} \\
& \text { I-nyong tan-sahh } k u-c i-w a-w i t \underline{a}-d o h \text { pa-pan } \grave{e}
\end{aligned}
$$

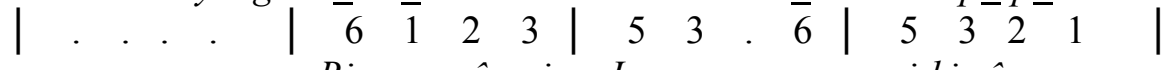

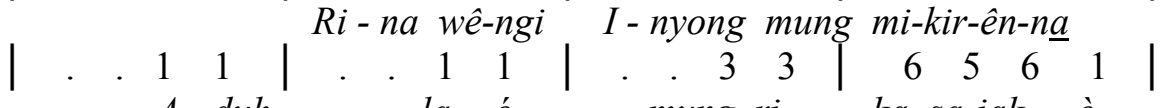

$$
\begin{aligned}
& \underline{A}-d u h \quad \text { la }-\dot{e} \quad \text { mung ri }-k \underline{a} \text { s } \underline{a}-j \underline{a} k-\dot{e}
\end{aligned}
$$

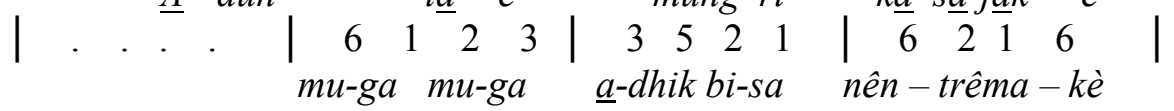

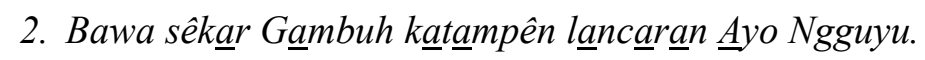

\section{A. Bawa Sêk $\underline{a r}$ Gambuh}

$$
\begin{aligned}
& \begin{array}{lllllll}
1 & 2 & 3 & 2 & 1 & 6 & \underline{5.32 .6}
\end{array} \\
& \text { A - ja sê - nêng ngê - la - mun } \\
& \begin{array}{lllllllll}
3 & 5 & 56 & 5 & 3 & 5 & 6 & 1 & \text { 213.2.16 }
\end{array} \\
& \text { A - ja nga - ya mun - dhakk ge - lis pi - kun } \\
& \begin{array}{lllllllllll}
6 & 6 & 6 & \underline{56} & 3 & 5 & 6 & \underline{1.232} & 6 & 5 & \underline{56} \\
\underline{5.32}
\end{array} \\
& T \underline{a}-b \grave{e} \text { - ri } \overline{y a} s \underline{a}-b \underline{a r} \quad s \underline{a} \text { - réh ma - was dhi -ri } \\
& \begin{array}{llllllll}
2 & 2 & 2 & 2 & 3 & 5 & \underline{561} & \underline{6.53}
\end{array} \\
& K u-w \underline{a}-j i b-\underline{a n} \quad k u-d u \quad \underline{r a m}-\underline{p u n g}
\end{aligned}
$$

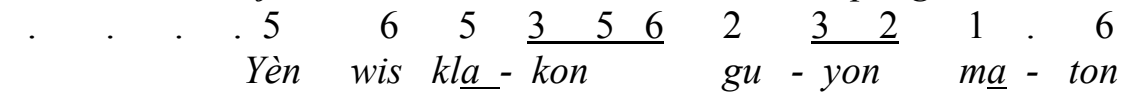

$$
\begin{aligned}
& \text {. } .6 \mathrm{G}
\end{aligned}
$$

\footnotetext{
5 Asal Sugiarto. "Kumpulan Gendhing Jawa Karya Ki Nartosabdo, Proyek Pengembangan Seni Budaya Daerah Jawa Tengah, Pemerintah Propinsi Dati I Jawa Tengah, Semarang. 1996/1997, 44.
} 


\section{B. Balungan Gending.}

$$
\begin{array}{lllllllllllllllll}
. & . & 5 & 6 & . & . & 5 & 6 & . & . & 5 & 6 & . & . & 5 & 6 \mathrm{G} \\
. & 3 & . & 5 & . & 6 & . & 5 & . & 3 & . & 2 & . & 1 & . & 2 \mathrm{G} \\
. & . & . & 3 & . & 5 & . & 6 & . & 5 & . & 3 & . & . & . & 1 \mathrm{G} \\
. & 3 & . & 5 & . & 6 & . & 5 & . & 1 & . & 2 & . & 1 & . & 6 \mathrm{G} \\
. & 2 & . & 1 & . & 2 & . & 3 & . & 1 & . & 6 & . & 1 & . & 2 \mathrm{G} \\
. & 1 & . & 6 & . & 5 & . & 3 & . & 5 & . & 6 & . & 5 & . & 6 \mathrm{G} \\
. & . & 5 & 6 & . & . & 5 & 6 & . & . & 5 & 6 & . & . & 5 & 6 \mathrm{G} \\
. & 5 & . & 6 & . & 5 & . & 3 & . & 2 & . & 1 & . & . & . & 6 \mathrm{G} \\
. & . & 5 & 6 & . & . & 5 & 6 & . & . & 5 & 6 & . & . & 5 & 6 \mathrm{G} \\
. & 5 & . & 6 & . & 5 & . & 3 & . & 2 & . & 1 & . & 2 & . & 6 \mathrm{G}-\mathrm{A}
\end{array}
$$

\section{Lêlagon (suara I)}

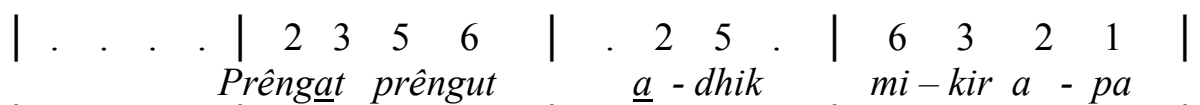

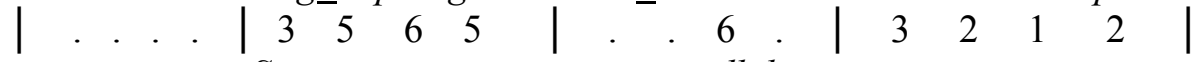

$$
\begin{aligned}
& \text { Sang-ga u-wang } \underline{a} \text {-dhik tan-pa gu-na }
\end{aligned}
$$

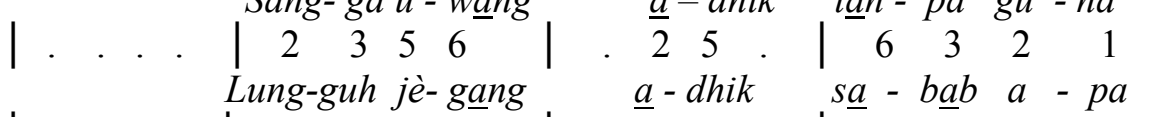

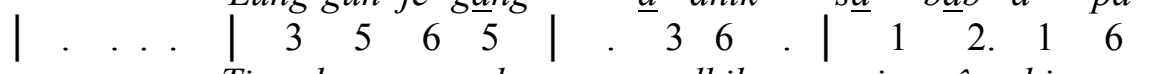

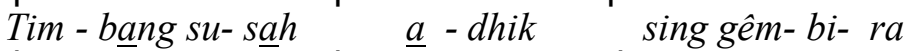

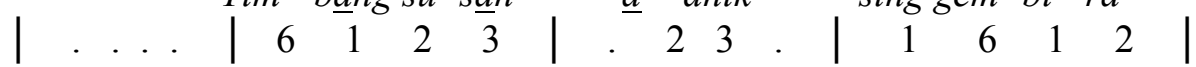

$$
\begin{aligned}
& \text { Yèn gêm-bi-ra } \underline{a} \text {-dhik pan-jang yus-wa }
\end{aligned}
$$

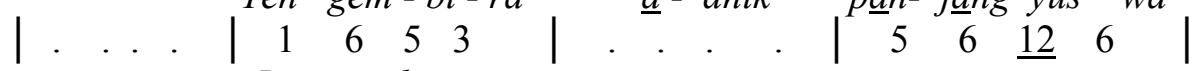

$$
\begin{aligned}
& \text { Ja nga -lá-mun } \quad \underline{a}-y o n g g u-y u
\end{aligned}
$$

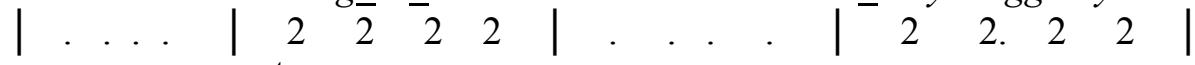

$$
\begin{aligned}
& \underline{A}-y o n g g u-y u \quad \underline{a}-y o n g g u-y u \\
& \text { |. . . . } \mid \begin{array}{rrrr|llll|l|lll|}
5 & 6 & 5 & 3 & 5 & 6 & 2 & 1 & 3 & 2 & 1 & 6
\end{array} \\
& \text { Tim - bang su-sah } \underline{a} \text {-dhik } \underline{a}-y o \quad p a-d h a \text { nggu-yu }
\end{aligned}
$$

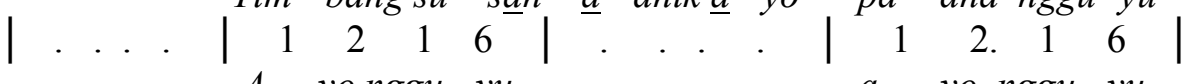

$$
\begin{aligned}
& \underline{A}-\text { yo nggu - yu } \underline{a}-y o n g g u-y u \\
& \text { |. . . }\left|\begin{array}{|cccc|cccc|ccc|}
5 & 6 & 5 & 3 & 5 & 6 & 2 & 1 & 3 & 2 & 1
\end{array}\right| \\
& \text { Tim-bang su-sah } \quad \underline{a} \text {-dhik } \underline{a}-y o \quad p a-d h a \text { nggu-yu }
\end{aligned}
$$

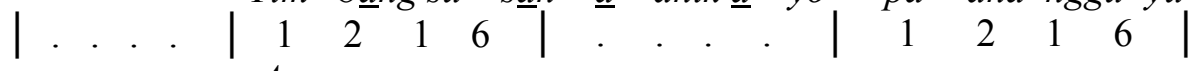

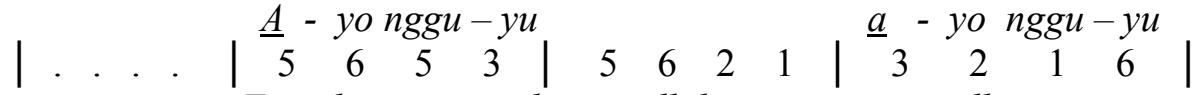

$$
\begin{aligned}
& \text { Tim-bangsu-s } \underline{a} h \quad \underline{a} \text {-dhik } \underline{a}-y o \quad \text { pa - dha nggu-yu }
\end{aligned}
$$

$$
|\cdot . \cdot| \cdot . \quad .|\cdot . \underset{M i-k i r}{2 \underset{1}{1} \mid} \cdot \underset{a-p a}{6}|
$$

${ }^{6}$ Asal Sugiarto, 1994/1995, 104. 


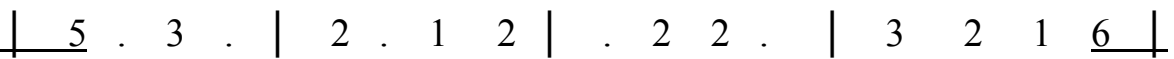

$$
\begin{aligned}
& \text { Sang - ga u-wang } \underline{a} \text { - dhik tan-pagu-na } \\
& |.23 \cdot| \cdot \cdot \cdot|\cdot 2 \cdot 1| \cdot \cdot 6+64 \mid
\end{aligned}
$$

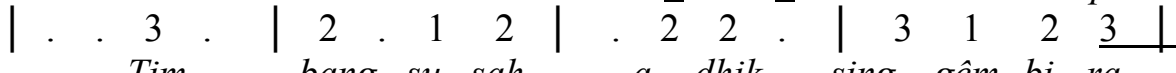

$$
\begin{aligned}
& \text { Tim - bang su-sah } \underline{a} \text {-dhik sing-gêm- bi-ra }
\end{aligned}
$$

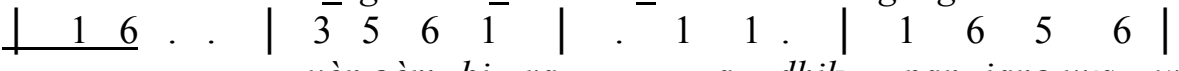

$$
\begin{aligned}
& \text { yèn gèm- } b i-r a \quad a \text {-dhik pan-jang yus-wa }
\end{aligned}
$$

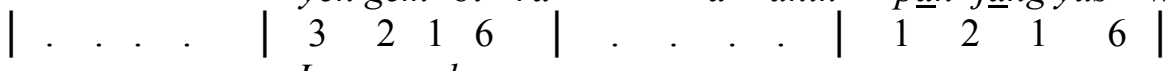

$$
\begin{aligned}
& \text { Ja nga } \underline{a} \text {-la-mun } \quad \underline{a}-y o n g g u-y u
\end{aligned}
$$

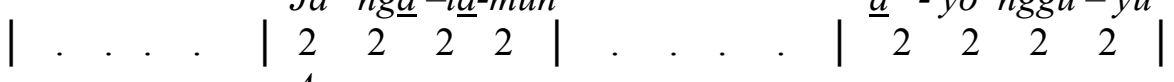

$$
\begin{aligned}
& \text { A - yo nggu-yu } \quad \underline{a}-y o n g g u-y u
\end{aligned}
$$

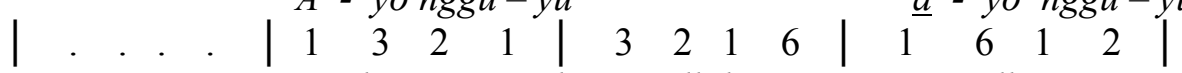

$$
\begin{aligned}
& \text { Tim-bang su-sah } \underline{a} \text {-dhik } \underline{a}-y o \quad \text { pa - dha nggu-yu }
\end{aligned}
$$

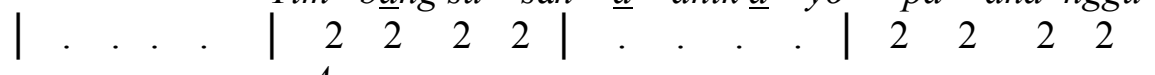

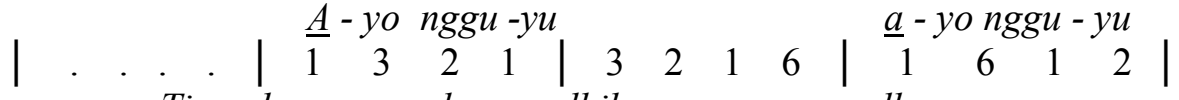

$$
\begin{aligned}
& \text { Tim-bang su-sah } \underline{a} \text {-dhik } \underline{a}-y o \quad p a-d h a \text { nggu-yu }
\end{aligned}
$$

\section{Bawa sêkar Kinanthi katampên lancaran Kagok Banyuwangèn.}

\section{A. Bawa Sêkar Kinanti}

$$
\begin{aligned}
& \begin{array}{llllllll}
6 & 6 & 1 & 2 & 1 & 6 & 21 & \underline{1.2}
\end{array} \\
& E \text {-suk é -suk num-pakpra- } u \\
& \begin{array}{llllllll}
1 & 2 & 3 & \underline{2.3} & \underline{1.6} & \underline{63} & \underline{5353} & 3
\end{array} \\
& \text { Ing pê-si-sir Ba- nyu-wa-ngi } \\
& \begin{array}{llllllll}
3 & 3 & 5 & 6 & 5 & \underline{32} & \underline{3232} & 2
\end{array} \\
& \text { Ing wê-tan sêm- bu - rat } \underline{a} \text { - bang } \\
& \begin{array}{lllllllll}
6 & 6 & 5 & 3 & 2 & 6 & 16 & 16 & 6
\end{array} \\
& \text { Sur-ya an-dung -kap ma- dhang- } i \\
& \begin{array}{llllllll}
3 & 2 & 3 & 2 & 6 & 53 & 53 & 3
\end{array} \\
& \text { Pu-lo Ba -li ka - ton cê - tha } \\
& \begin{array}{lllllll}
6 & 5 & 3 & 2 & 6 & 6 & 5.6
\end{array} \\
& \text { En-dáah ba-ya } \underline{a}-n g r \underline{a}-\text { wit }
\end{aligned}
$$

B. Balungan Gending.

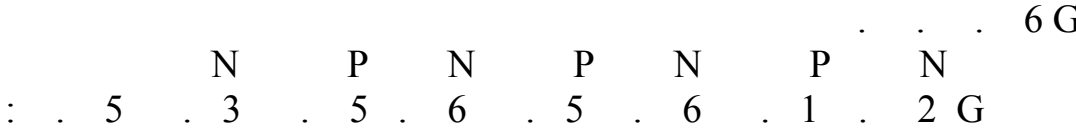

$$
\begin{aligned}
& \text {. } 5 \cdot 3 \cdot 5 \cdot 6 \cdot 5 \cdot 3 \cdot 2 \cdot 1 \mathrm{G} \\
& \text {. } 5 \cdot 3 \cdot 2 \cdot 1 \cdot 2 \cdot 3 \cdot 1 \cdot 2 \mathrm{G} \\
& \text {. } 3 \cdot 2 \cdot 6 \cdot 1 \cdot 2 \cdot 3 \cdot 1 \cdot 2 \mathrm{G} \\
& .5 .3 .5,6.5 .5 \% 2.16 \\
& .5 .3 .5 .2 .5 .6 .5 .3 \mathrm{G}
\end{aligned}
$$

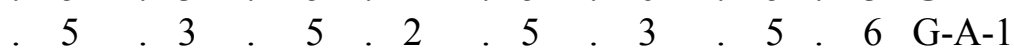


C. Lêlagon. ${ }^{7}$

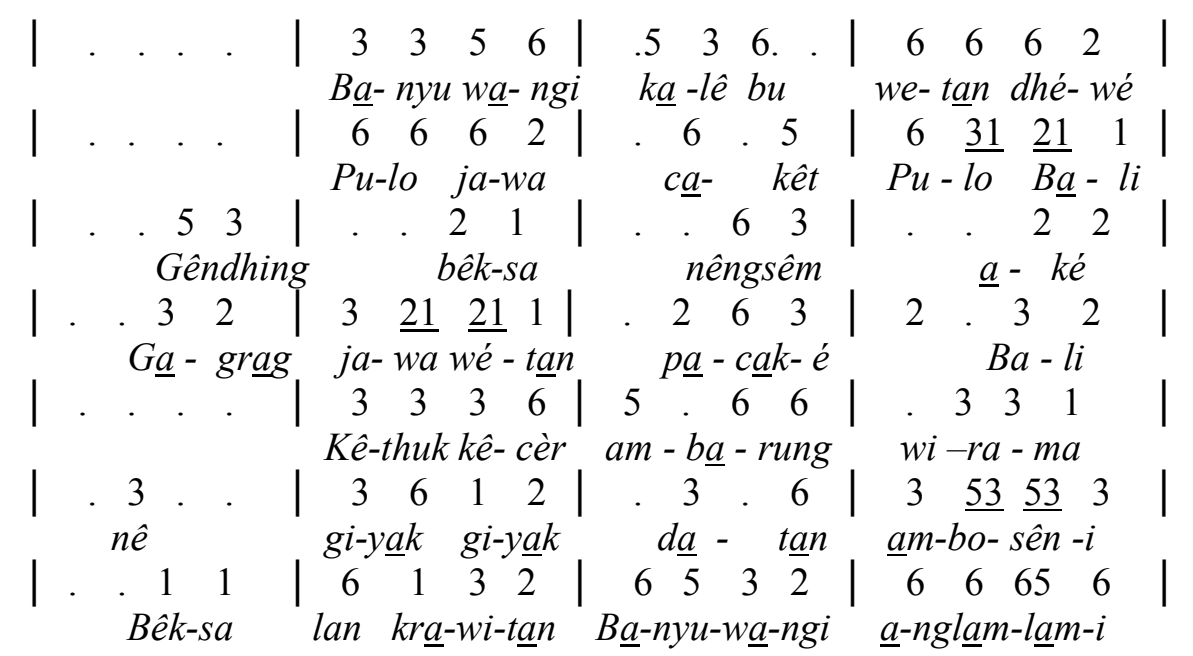

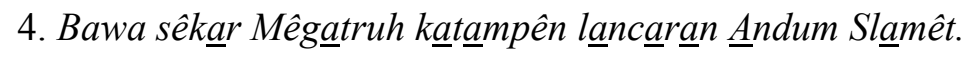

A. Buka Bawa Sêkar Mêgatruh

$$
\begin{aligned}
& \text { Yèn mang-ko-no ni - mas } \dot{a}-\dot{k} u \text { tri }-m a \quad \dot{m u n-d u r} \cdot \\
& \text { Tan - pa gu - na tan - sáh nyan - dhing } \\
& \dot{M a} \text { - rang kangtan wêtruh, pra - yo-ga } \cdot \dot{a}-k \dot{k} \text { nying - kir } \\
& N \underline{a} \text { - dyan yêk - ti - né su - mêe - dhot }
\end{aligned}
$$

B. Balungan Gending.

$$
\begin{aligned}
& \begin{array}{rlllllllll} 
& \mathrm{N} & \mathrm{P} & \mathrm{N} & \mathrm{P} & \mathrm{N} & \mathrm{P} & \mathrm{N} & \mathrm{G}
\end{array} \\
& .5 .6 .1 .6 \quad 5.3 .1 .2 \mathrm{G}
\end{aligned}
$$

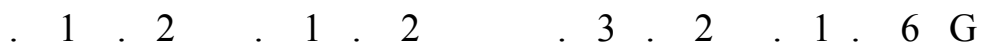

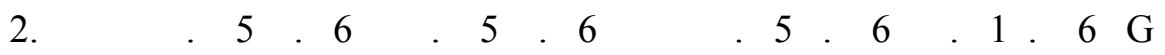

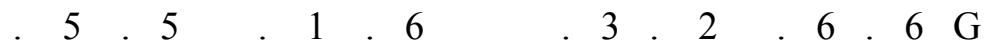

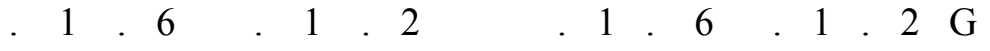

$$
\begin{aligned}
& .1 .2 .1 .62 .6 .5 .3 .6 \mathrm{G}
\end{aligned}
$$

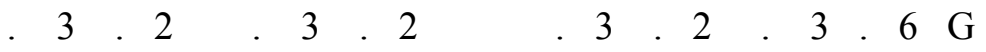

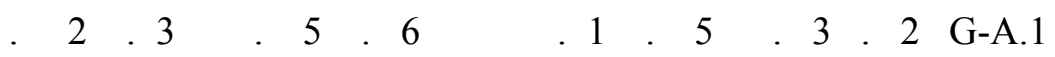

${ }^{7}$ Asal Sugiarto, 1994/1995, 71. 
C. Lêlagon. ${ }^{8}$

$$
\begin{aligned}
& \text { |. . . }|\cdot . \quad .| . \underset{L u-w u n g}{5} 6 \mid \cdot \frac{7 \quad 5}{p \hat{e}-d h o t}
\end{aligned}
$$

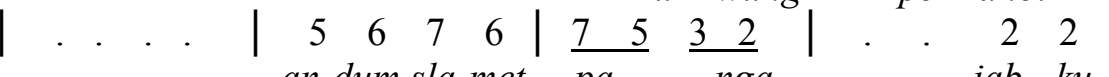

$$
\begin{aligned}
& \text { an-dum sla-met } \underline{p} \underline{a}-n g \underline{a} \quad-j \underline{a} b-k u
\end{aligned}
$$

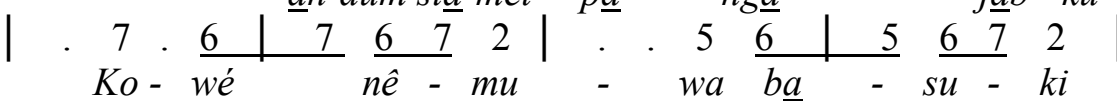

$$
\begin{aligned}
& \left|\cdot \frac{13}{s u-k a}\right| \cdot \frac{13}{s u-} \frac{2}{k a} \quad \frac{61}{i n g-k a n g} \frac{\overline{5} \mid}{n u}-\frac{35}{n u}-t u
\end{aligned}
$$

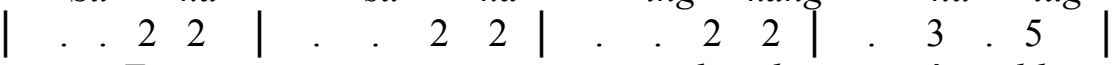

$$
\begin{aligned}
& \text { Tanngi - } r a \underline{a}-k u k \hat{e} \text { - cé - lik }
\end{aligned}
$$

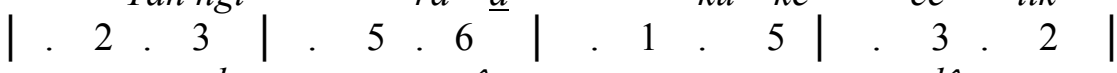

$$
\begin{aligned}
& \text { Tan - sah } n g \underline{a}-c \hat{e}-\quad m o n g \text { nya }-l \hat{e}-m o n g
\end{aligned}
$$

3. Bawa sêkar Pangkur kạtämpên lancaran Éling-éling Banyumásan.

A. Buka Bawa Sêkar Pangkur.

$$
\begin{aligned}
& \begin{array}{llllllll}
6 & 6 & 6 & 2 & 3 & 4 & \underline{43} & \underline{4.3}
\end{array} \\
& \text { Ra-dèn Har- y } \underline{a} \text { Wêr- ku-da- }-\underline{a} \\
& \begin{array}{lllllllllll}
3 & 4 & 6 & 6 & 3 & 3 & 3 & 3 & 3 & 34 & \underline{3.432}
\end{array}
\end{aligned}
$$

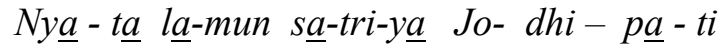

$$
\begin{aligned}
& \begin{array}{lllllllll}
2 & 2 & 3 & \underline{4.3234} & 2 & 2 & 2 & \underline{2.76 .} 5676
\end{array} \\
& \text { Prá-ko-sa ga - gahh gung lu - lur } \\
& \begin{array}{lllllll}
6 & 7 & \underline{1.76 .71 .} & 6 & 6 & 6 & \underline{6.43 .423}
\end{array} \\
& \text { Godhég wok sim-bar ja - ja } \\
& \begin{array}{llllllllllll}
3 & 4 & 6 & 6 & 2 & \underline{3.4} & 6 & 6 & 3 & 3 & \underline{34} & \underline{3.432}
\end{array} \\
& \text { Yèn ngan-di-ka gêe-rêng gêe-rêng pin- dha gun tur } \\
& \begin{array}{llllllll}
2 & 5 & 5 & 5 & 5 & 7 & 5 & \underline{56}
\end{array} \\
& \text { Dha - sar sa-tri - ya pra-wi- ra } \\
& \begin{array}{llllllll}
4 & 32 & 2 & 3 & 2 & 3 & 34 & 3.2
\end{array} \\
& \text { Rá-ma é-ling ku-la é- ling }
\end{aligned}
$$

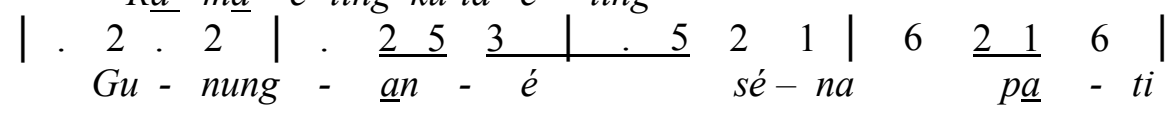

B. Balungan Gending.

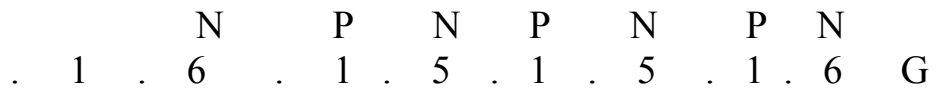

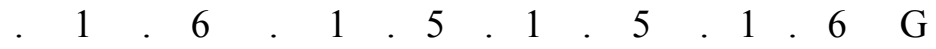

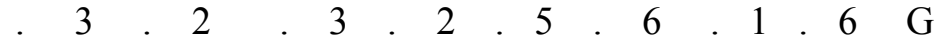

$$
\begin{aligned}
& \text {. } 6.5 .3 .6 .5 .6 .1 .6 \text { G -A }
\end{aligned}
$$

\footnotetext{
${ }^{8}$ Asal Sugiarto, 1994/1995, 4.
} 
C. Lêlagon. ${ }^{9}$

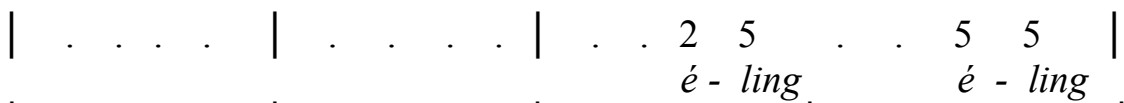

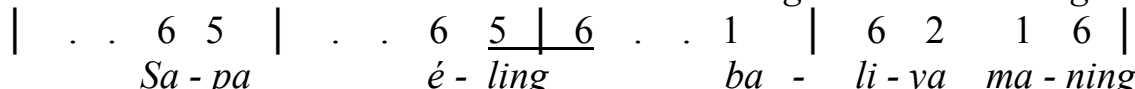

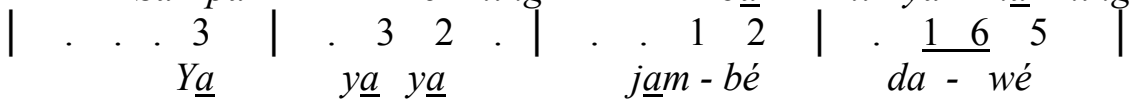

$$
\begin{aligned}
& \bar{J} \underline{a}-n u r \quad g u-\text { nung }
\end{aligned}
$$

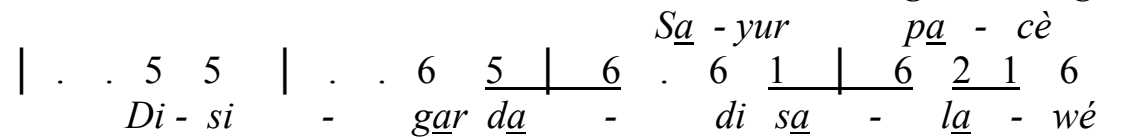

$$
\begin{aligned}
& S \underline{a}-k u \text { - lon Ban - jar-pa - tom - an } \\
& \text { lêm-ba - yung pa - it ra }-s \underline{a}-n e ́
\end{aligned}
$$

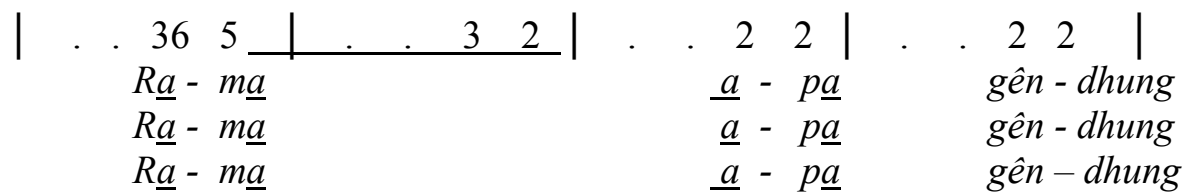

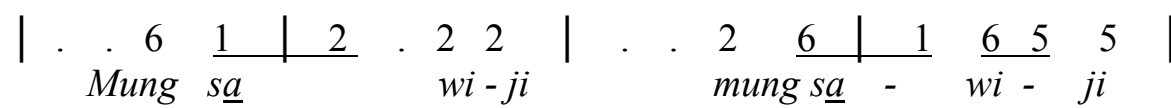

$$
\begin{aligned}
& K \underline{a}-d i \quad n g \underline{a}-r e n \quad k \underline{a}-d i-n g a-r e ́ n \\
& M a-s a \quad b o-\text { rong } m a-s a \quad b o-r o n g
\end{aligned}
$$

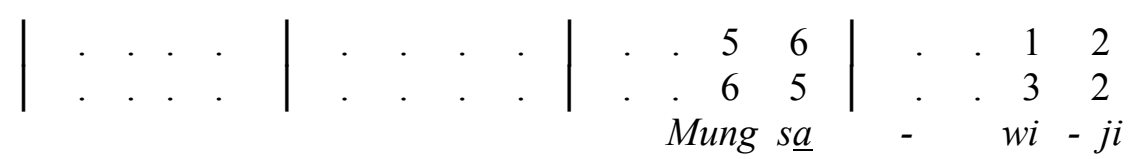

$$
\begin{aligned}
& K \underline{a}-d i \quad-\quad n g \underline{a}-r e ́ n \\
& M a-s a \quad b o-r o n g
\end{aligned}
$$

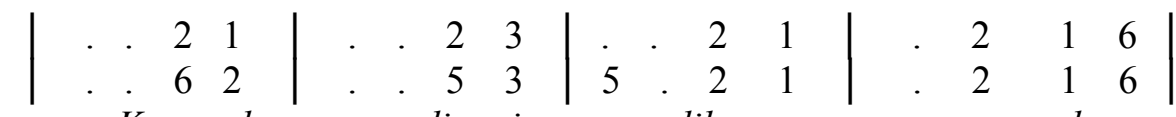

$$
\begin{aligned}
& \text { Kang } d \underline{a}-d i p i \text { - lih- } \underline{a} n-n \underline{a} n-k u \\
& \text { Wong ba - gus ga - sik tê - } k a \text { - né } \\
& \text { Ku - la ndhé-rék sa-kêr - sa - né }
\end{aligned}
$$

6. Bawa sêkar Asmarandana katampên Lancaran Godril Banyumasan.

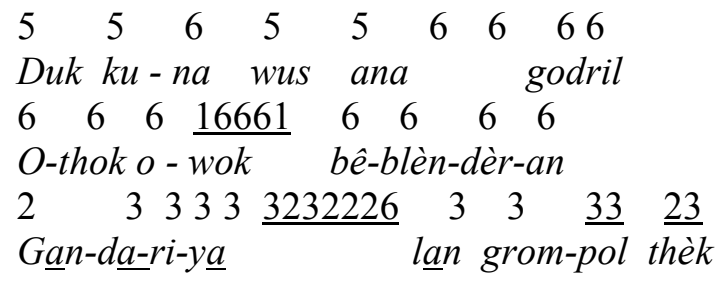

${ }^{9}$ Asal Sugiarto, 1994/1995, 31. 
$\begin{array}{llllllll}2 & 2 & 3 & \underline{26} & 3 & 3 & 3 & 3\end{array}$

Ru-jakk jê-ruk ma-ta-ram- $\underline{a} n$

$\begin{array}{lllllll}2 & 2 & 2 & 2 & 2 & 2 & 2\end{array}$

Ka-long-king lan gan-dar-wa

$\begin{array}{llllllll}6 & 6 & 1 & \underline{63} & 3 & \underline{13} & \underline{33} & \underline{23}\end{array}$

Mo-mong su -ta ju-rang ju-grug

$\begin{array}{llllllll}2 & 2 & 21 & 6 & \underline{12} & 3 & \underline{21} & 2\end{array}$

Bri-bil gon-jol sa- s $\underline{a}-m i r-\underline{a n}$

$\begin{array}{lllll}\text { Nyêkar: } & 6262 & 6356 & 2132 & 6535 \\ & 235 . & 1653 & 6132 & 6312\end{array}$

Nyêkar laras miring

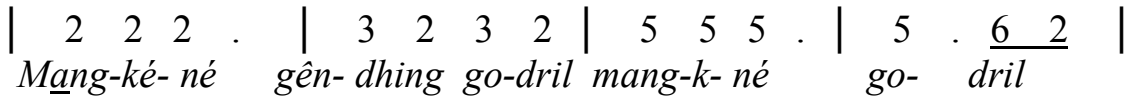

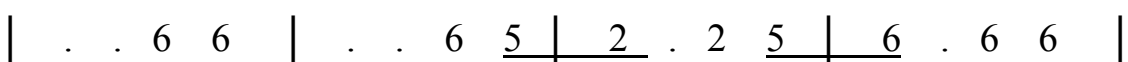

Bu-di da $-y \underline{a}-$ nên mrih ka-sil

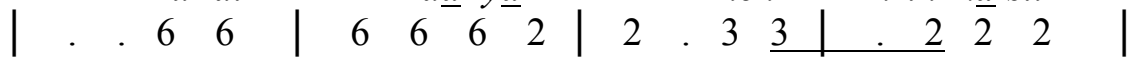

A-ja ja-il mêtha-kil a-ja ngru-wil

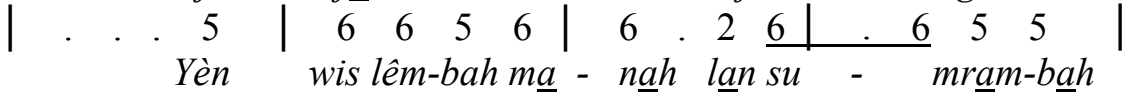

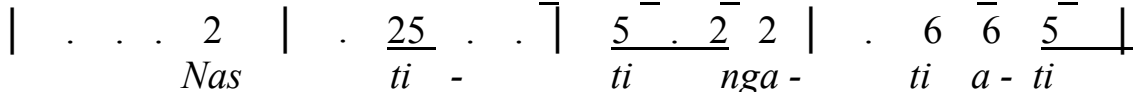

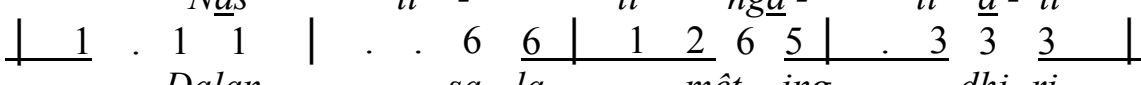

Dálan $\quad s \underline{a}-l \underline{a}-m e t$ ing dhi -ri

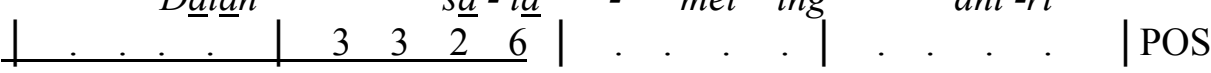

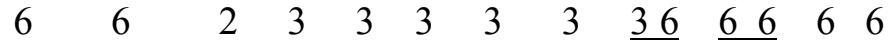

Ka -kang mBak-yu tho-lé gên-dhuk Ra - ma I-bu

$\begin{array}{llllllllll}33 & 6 & 5 & 6 & 6 & 6 & 5 & 6 & 6 & \underline{65666.332333}\end{array}$

La-mun tan-dang tan-duk ting-kah la $-k u$

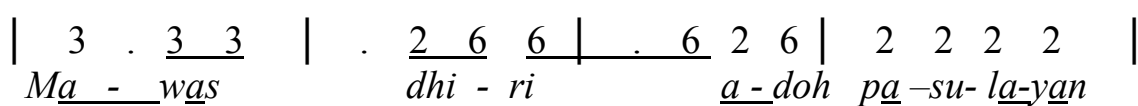

(Gatot Sasminto, 2000: 107).

6. Bawa sêkar Sinom, kâtampên lancaran Aja Rèwèl.

A. Bawa.

$\begin{array}{llllllll}1 & 2 & 2 & 2, & 2 & \underline{23} & 1 & \underline{21}\end{array}$

A-nák-ku tạk lé- la lé - la

$\begin{array}{llllllll}1 & 1 & 1 & 1 & 1 & 1 & \underline{62} & \underline{12165}\end{array}$

Cêp mêe-nê-nga a - ja na-ngis

$\begin{array}{llllllll}1 & 2 & 3 & 12 & 6 & 6 & \underline{653} & \underline{56}\end{array}$ 
Anggèr ko wé nja-luk a - pa

$\begin{array}{llllllll}5 & 6 & 6 & 6 & \underline{6165} & \underline{356} & \underline{23} & \underline{1.216}\end{array}$

Wa-ton ko-wé a - ja na - ngis

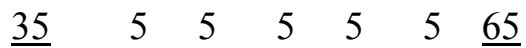

I - bu-mu mun-dhak sê - dhih

$\begin{array}{llllllll}5 & 6 & 1 & \underline{2321} & 6 & \underline{35} & \underline{565} & \underline{32}\end{array}$

Lu-wih bê-cik mè-sêm nggu-yu

$\begin{array}{llllllll}1 & 2 & 3 & 3 & 3 & 3 & \underline{23} & \underline{123}\end{array}$

$A$ - na k - ku ták ku-dang $k u$ - dang

$\begin{array}{llllllll}5 & 6 & \underline{6532} & \underline{356} & 2 & 2 & \underline{23} & \underline{1216}\end{array}$

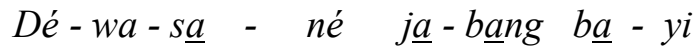

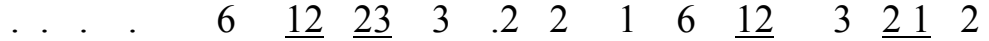

Mu-ga mu-ga da-di bo-cah kang u-ta - ma.

\section{B. Balungan Gending.}

Irama sêsêg

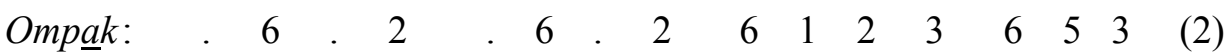

Nyêkar:

$\begin{array}{llllllllllllllll}. & 3 & . & 2 & . & 3 & . & 5 & . & 1 & . & 6 & . & 3 \\ . & 6 & . & 2 & . & 6 & . & 2 & . & 3 & . & 5 & . & 3 \\ . & 6 & . & 2 & . & 6 & . & 2 & . & 5 & . & 6 & . & 5 \\ . & 5 & . & 3 & . & 2 & . & 1 & . & 3 & . & 2 & . & 1 \\ . & 1 & . & 6 & . & 3 & . & 5 & . & 3 & . & 2 & . & 1 \\ . & 6 & . & 3 & . & 6 & . & 5 & . & 6 & . & 1 & . & 1 \\ . & 6 & . & . & . & . \\ . & 6 & . & 3 & . & 6 & . & 5 & . & 2 & . & 3 & . & 1 & . \\ .\end{array}$

C. Lêlagon. ${ }^{10}$

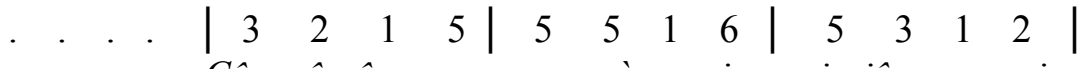

$$
\begin{aligned}
& \text { Cêp mê-nêng - a } \underline{\text { ang-gèr } a-j a ~ p i-j e ̂ r ~ n a-n g i s ~}
\end{aligned}
$$

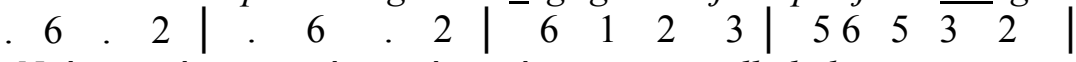

$$
\begin{aligned}
& \text { Ngèr-ngèr } \quad \text { ngèr ngèr yèn na-ngis ndhak ilang manisê }
\end{aligned}
$$

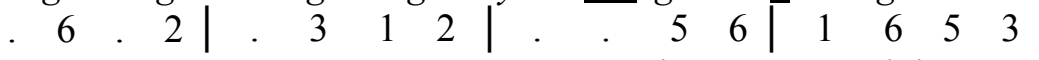

$$
\begin{aligned}
& \text { Cêp cêp mê-nê-nga ko-wé nja-luk a-pa }
\end{aligned}
$$

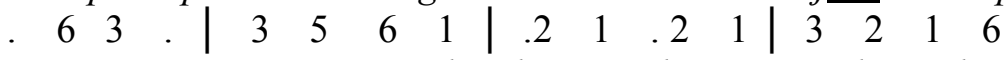

$$
\begin{aligned}
& \text { Ang-gèr } \quad a-j a \quad w \hat{e}-d i \quad b \underline{a-r a n} \text { kang nga-nèh- } \underline{a-n e ̀ h-i} \\
& \begin{array}{llll|llll|lll|llll|}
.1 & 6 & .1 & 6 & 3 & 5 & 6 & 5 & 3 & 2 & 3 & 2 & . & 1 & 2
\end{array} \\
& i \text {-ku pan-cèn } u \text {-wis mês-thi ang-gèr } a \text {-ja na-ngis }
\end{aligned}
$$

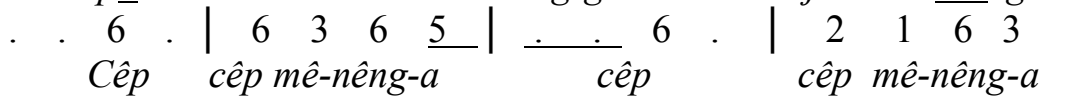

\footnotetext{
${ }^{10}$ Gatot Sasminto. Kumpulan Gêndhing-Gêndhing Lan Lagon Dolanan Ki Nartosabdo, Jilid I, II, III. CV. Cenderawasih, Surakarta, 1994, 3.
} 


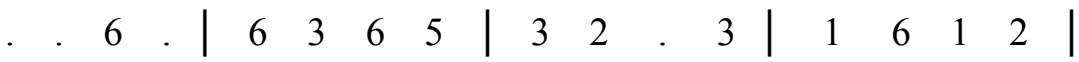

$$
\begin{aligned}
& \text { Pa - dha mu-lih-a ka - lis sa -kèh-ing go-dha }
\end{aligned}
$$

\section{Bawa sêkar Dhandhanggula kátampên ladrang Bribil.}

A. Bawa :

$$
\begin{aligned}
& \begin{array}{llllllllll}
7 & 2 & 2 & 2 & 2 & 3 & 3 & 3 & 3 & 3
\end{array} \\
& \text { Nêng-gih wa - u ya-ta sang } \underline{A}-y o-g i \\
& \begin{array}{llllllllll}
2 & 2 & \underline{23} & 2 & 7 & 6 & 6 & 6 & 6 & \underline{5.6}
\end{array} \\
& \underline{A}-\text { nim- } \underline{b a l}-i \text { sang-gya pa-ra sis- wa } \\
& \begin{array}{llllllll}
7 & 2 & \underline{23} & 2 & 7 & 6 & \underline{76} & \underline{5.6}
\end{array}
\end{aligned}
$$

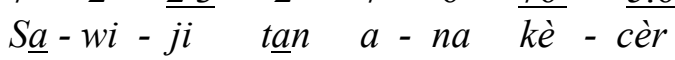

$$
\begin{aligned}
& \begin{array}{lllllll}
6 & 7 & 2 & 2 & 2 & 234 & 3.2
\end{array} \\
& \text { Hi-yêk sa-yuk tu mung - kul } \\
& \begin{array}{lllllllll}
7 & 67 & 3 & 2 & 2 & 2 & 2 & 2 & 2
\end{array} \\
& \text { Pra jê - jang - gan mi - wahh pra can - trik } \\
& \begin{array}{llllllll}
7 & 2 & 3 & 1 & 3 & 3 & 3 & 3
\end{array} \\
& \underline{A} \text { - glär nèng pa -dhé - pok - an } \\
& \begin{array}{llllll}
2 & 7 & 2 & 232 & \mathbf{7 .} 6
\end{array} \\
& \underline{A}-\text { nya-dhong pi - tu }-\overline{t u r} \\
& \begin{array}{llllllll}
6 & 7 & 2 & 3 & 3 & 3 & 3 & 3
\end{array} \\
& \text { Mangka sa - ngu-ning } \underline{a}-g \hat{e}-s \underline{a n g} \\
& \begin{array}{llllllllllll}
2 & 2 & \underline{32} & 2 & 7 & 6 & 6 & 6 & 6 & 7 & \underline{23} & 3
\end{array} \\
& \text { Tri pra ka-ra ta-ta ti-ti tê-mah } \overline{t i}-t i s
\end{aligned}
$$

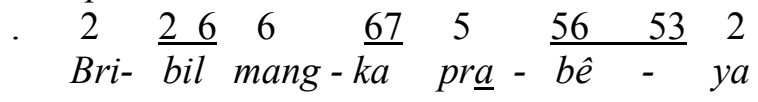

B. Balungan Gending:

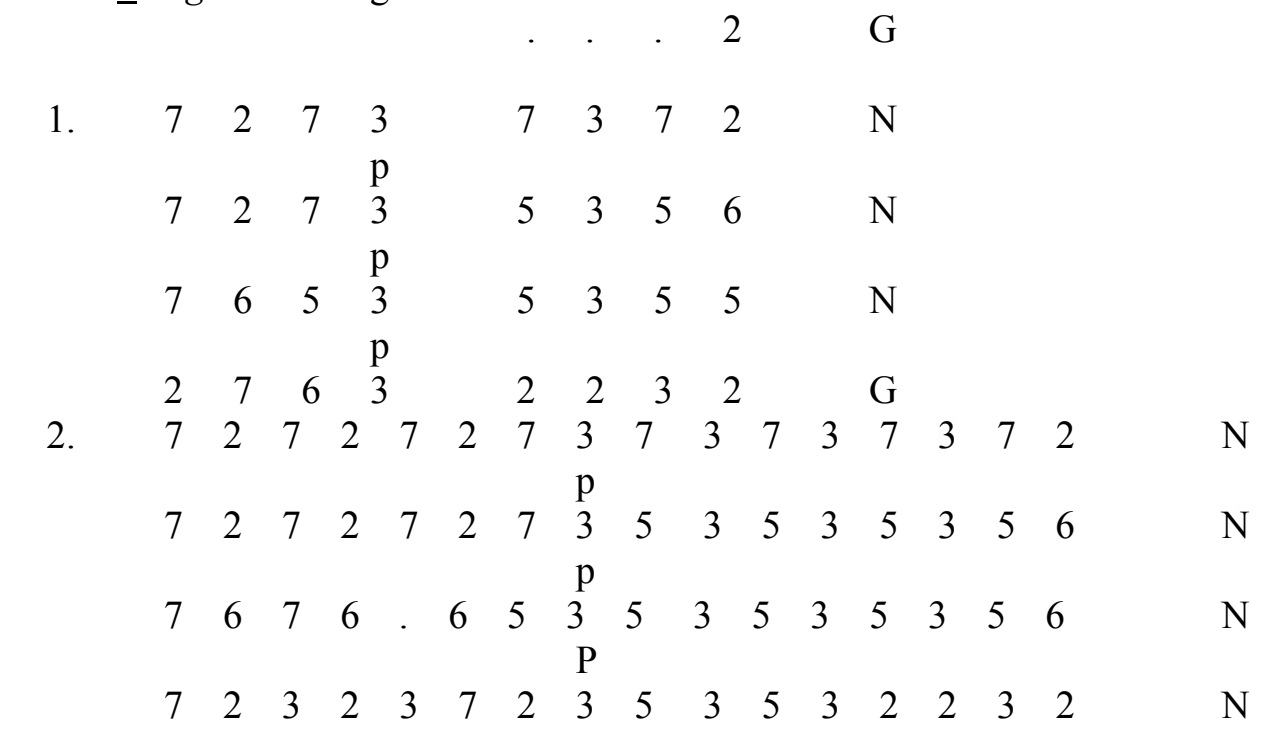


C. Gérongan. ${ }^{11}$

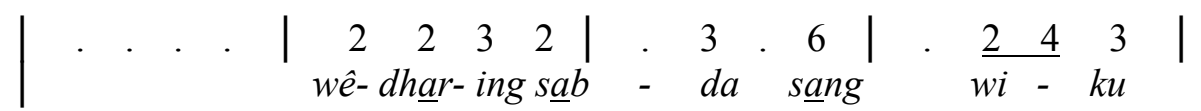

$$
\begin{aligned}
& C a-t u r \text { prá-ka - ra } k \underline{a}-c \underline{a}-k u p
\end{aligned}
$$

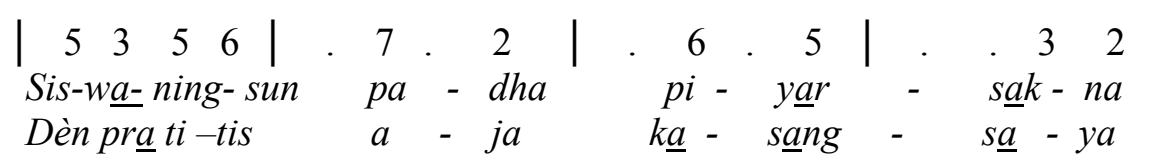

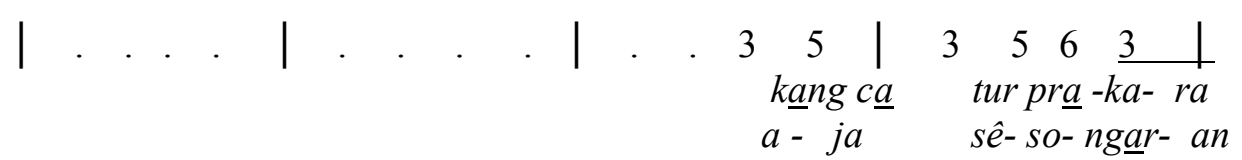

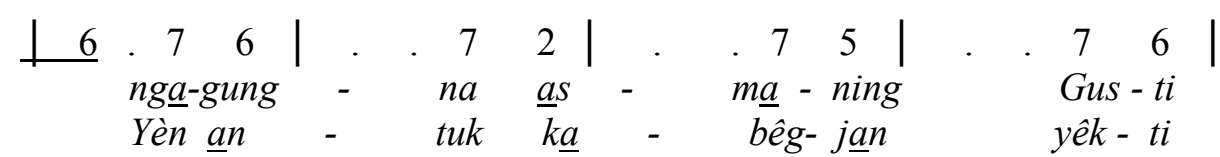

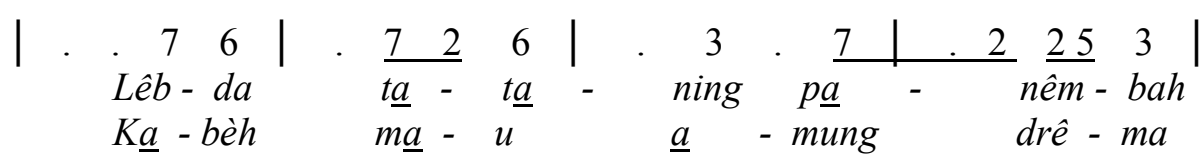

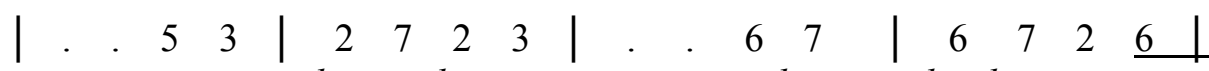

$$
\begin{aligned}
& \text { sar-ta ka-wruh-a-na wa-jib la -ko-a-na }
\end{aligned}
$$

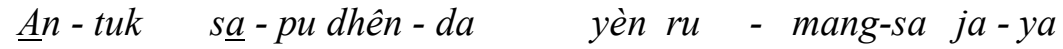

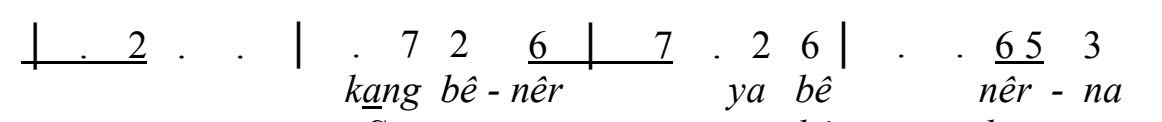

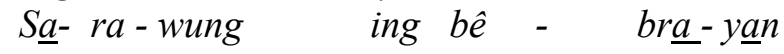

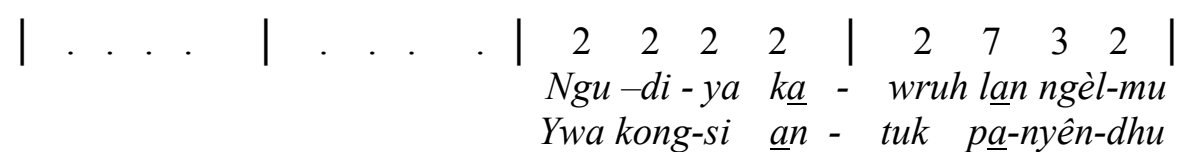

9. Bawa sêkar Pocung kạtampên Ladrang Pujimaya.

A. Buka.

$\begin{array}{llllllllllll}3 & \underline{656} & 1 & 1, & 1 & 2 & 3 & 23 & 6 & \underline{5.3} & \underline{616} & \underline{5.3}\end{array}$

$\underline{A}-k u$ gu-mun lán ma- nèh $k u-d u \underline{a n g}-g u-y u$

$3 \quad \underline{612} \quad 6 \quad 3 \quad \underline{3653216} \quad \underline{23.5321}$

$I$ - ki gên-dhing a - pa

$\begin{array}{lccccccc}6 & 6 & 6 & 6 & \frac{61}{5 u l} & \frac{532356}{k \hat{e}}- & \frac{235321}{p a}-\frac{1 \cdot 6}{t i}\end{array}$

Jinêman

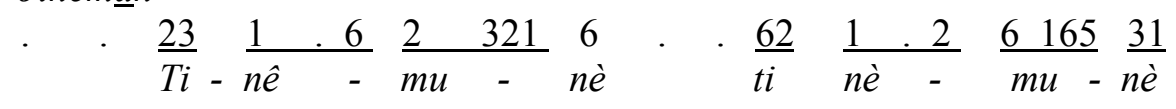

${ }^{11}$ Asal Sugiarto, 1996, 18. 


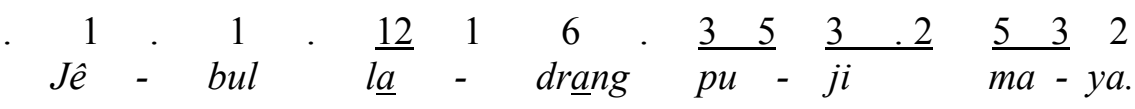

B. Balungan Gending.

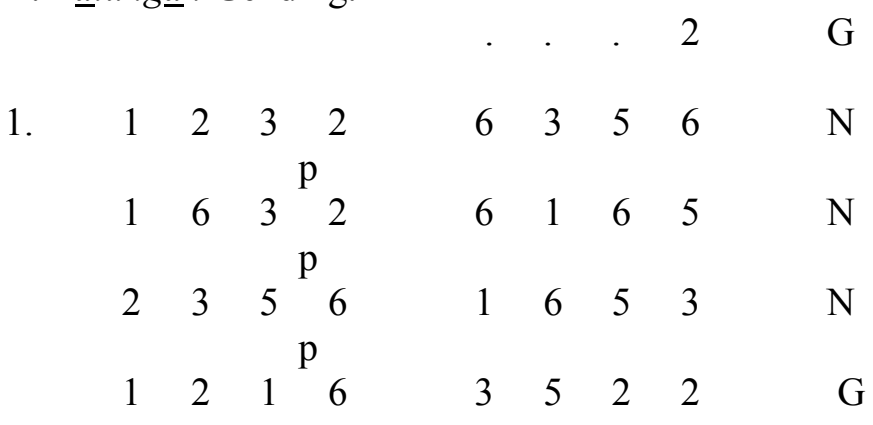

$\begin{array}{lllllllllllllllll}2 . & 1 & 2 & 1 & 6 & 3 & 5 & 3 & 2 & . & 3 & 2 & 1 & 6 & 5 & 3 & 5 \mathrm{~N}\end{array}$

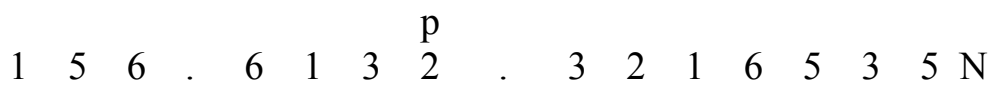

$\begin{array}{lllllllllllllllll}1 & 6 & 5 & 3 & 2 & 3 & 5 & 6 & 3 & 2 & 1 & 6 & 2 & 1 & 2 & 3 & \mathrm{~N}\end{array}$

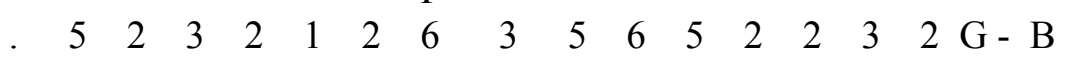

C. Gêrongan. ${ }^{12}$

1. Irama 1.

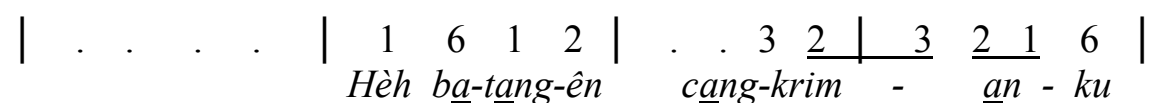

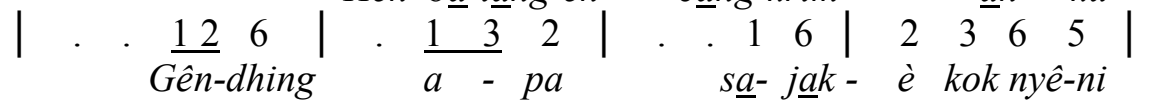

$$
\begin{aligned}
& \left|\begin{array}{lll}
2 & 3 & 5
\end{array}\right| \cdot \begin{array}{cccccc}
3 & 5 & 6 & \cdot & 2 & 1
\end{array}\left|\cdot \begin{array}{ccc}
6 & 3
\end{array}\right|
\end{aligned}
$$

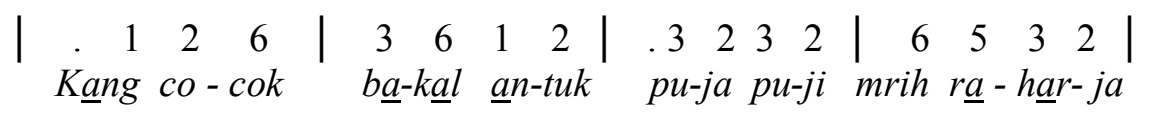

B. Gérongan.

Berbagai gérongan yang mengambil sumber Sêkar Macapat diungkapkan 6 (enam) macam, yaitu: (1) Gérongạn Pocung dalam Ladrang Pujimaya, (2) Gérongann, Mijil dalam Kêtáwang Mijil Panglilih, (3) Gérongan $\underline{a}$ smarandana dalam Lâdrang Asmarandana, (4) Gérongan dalam Ladrang Pangkur, (5) Gérongan dalam Ladrang

${ }^{12}$ Asal Sugiarto, 1996, 155. 
Pocung, (6) Gérongan Durma Ladrang Kagok. Adapun notasi lagu dan cakêppan atau syairnya sebagai berikut.

1. Gérongan Pocung dalam Ládrang Pujimaya. ${ }^{13}$

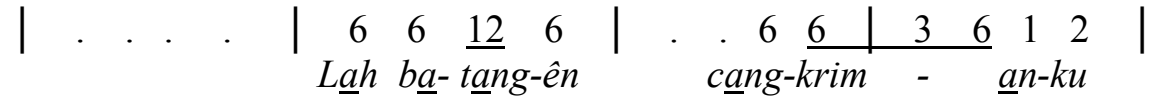

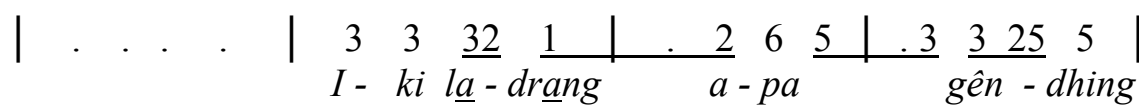

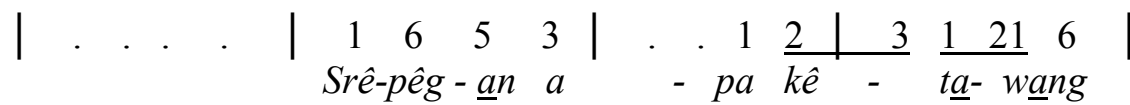

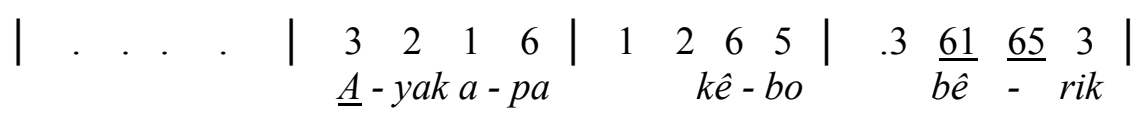

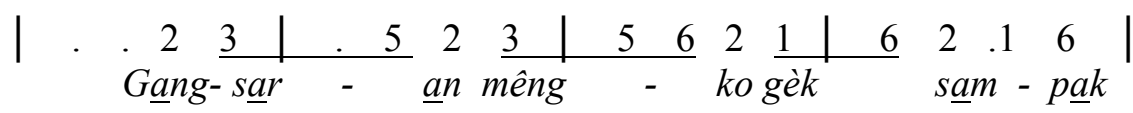

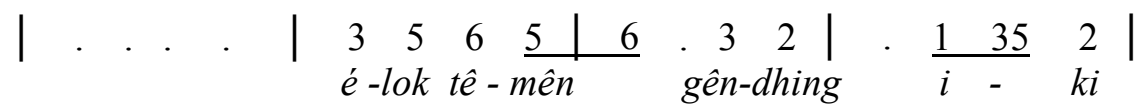

2. Gérongan, Mijil dalam Kêtawang Mijil Panglilih.

\begin{tabular}{|c|c|c|c|c|c|c|c|}
\hline & $\cdot$ & & . & . & & $\begin{array}{c}3 \\
P \underline{a} n-\end{array}$ & $\begin{array}{c}2 \\
\text { dam }\end{array}$ \\
\hline & . & & $\underline{3}$ & I & 2 & $\underline{3} 5$ & 5 \\
\hline & & & & & & mun & - car \\
\hline & . & - & . & . & $\underline{1}$ & .2 & 6 \\
\hline & & & & & $s u$ & - & $m u-$ \\
\hline & . & $\underline{36}$ & 5 & . & $\underline{5}$ & 653 & 2 \\
\hline & & luh & nуu & - & $n \underline{a}$ & - & $r i$ \\
\hline & & 12 & 3 & . & & 1 & 1 \\
\hline & & & & & & $S \underline{a}$ & jro \\
\hline & . & 1 & $\underline{1}$ & .6 & $\underline{1}$ & 23 & 1 \\
\hline & & ning & $p \underline{a}$ & - & tung & - & gon \\
\hline & . & & . & 1 & $\underline{45}$ & $\underline{56}$ & 5 \\
\hline & & & & $T i \quad-$ & - nêng & $g-g \underline{a}-$ & $n \underline{a} n$ \\
\hline & . & 1 & $\underline{2}$ & 36 & $\underline{35}$ & $\underline{65}$ & 3 \\
\hline & & $T \hat{e}-$ & guh & tan & ang & $-\quad g l \underline{a}-$ & $p e ́$ \\
\hline & . & . & . & 3 & 6 & $\underline{46}$ & $\underline{5}$ \\
\hline & & & & $K u-$ & $s u$ & - $\quad m a$ & - $y u$ \\
\hline & 6 & 2 & 6 & .1 & 2 & .3 & $\underline{3}$ \\
\hline
\end{tabular}

${ }^{13}$ Asal Sugiarto, 1996, 155. 


\begin{tabular}{|c|c|c|c|c|c|c|c|}
\hline 5 & 6 & kang & ko - & $n g \underline{a s}$ & prih & $\frac{a}{2}$ & $\begin{array}{l}\text { tin } \\
6\end{array}$ \\
\hline & & & & & ngrê & & $r i-$ \\
\hline & . & 35 & 5 & . & 56 & 53 & $\underline{2}$ \\
\hline & & pih & mrih & & $l i$ & - & lih \\
\hline & & 12 & 3 & . & 1 & . & 1 \\
\hline & & & & & Sang & & \\
\hline . & . & 1 & $\underline{1}$ & .6 & $\underline{61}$ & 23 & 1 \\
\hline & & kung & $k \underline{\underline{c}}$ & - & sên & & $d h u$ \\
\hline
\end{tabular}

Gèrongạn lainnya.

2. S Saduwa myang, amatur aririh

Dhuh Sang Prawiranom

Haywa konjêm marang mêmanisé

Pamicara kang tan trusing batin

Mung nêlêsi lathi

Tansah mawèh péncut

3. Sámpun kâdi, manungsa ndalêming

Ngêcêmong nyalêmong

Mámang mulat liringing nétrané

Upayané kang sêtya sêjâti

Tuhu anjalari

Kamulyaning kalbu. ${ }^{14}$

3. Gérongan Asmaradana Ladrang dalam Asmaradana.

$$
\begin{aligned}
& \text { |... . . . . . } \mid \begin{array}{lllll|llll|}
6 & 7 & 2 & 3 & 5 & 6 & 5 & 3
\end{array} \\
& \text { Pa-nêe-ngah Dè - wi Hu-lu-pi }
\end{aligned}
$$

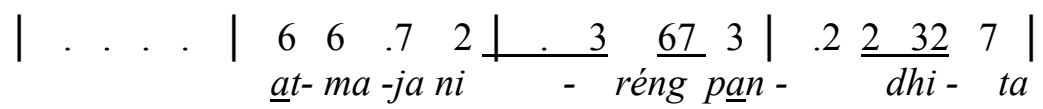

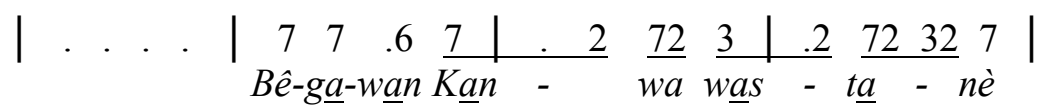

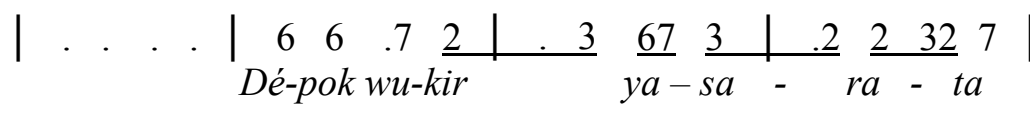

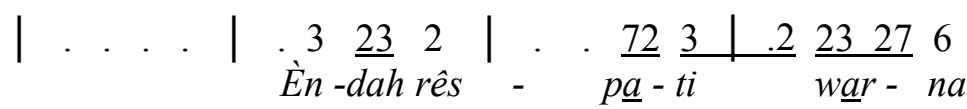

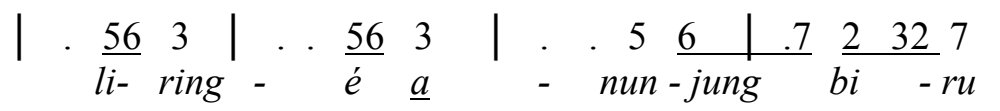

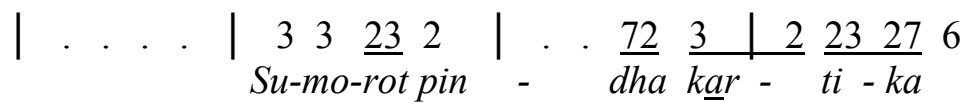

${ }^{14}$.Biman Putro, SW., 1994, 38. 
2. Dhèmês luwês mêrak $\underline{a}$ ti

Kati pratima rinêngga

Sarêntêg mbambang awakè

Mawèh branta kang tumingal

Liringa pindha wulan

Tan pêgat mahèsmu angguyu

Kéngis kang waja gumbyar

3. Antêngé wêka

Sumèh ing pamulunira

Pantês yèn amathêt lambé

Ngiras mintokaken waja

Wangun tètèsing toya

Kalamun baskara nrawung

Lir tranggana mrih sesame. ${ }^{15}$

4. Gérongan dalam Ladrang Pangkur. ${ }^{16}$

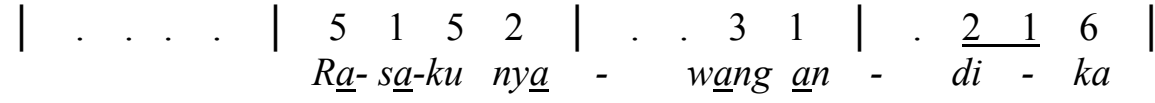

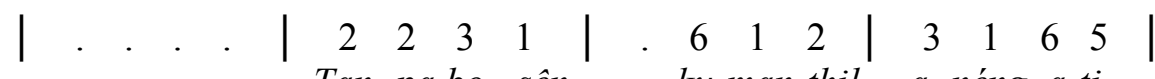

$$
\begin{aligned}
& \text { Tán-pa bo-sên ku-man-thil a-néng } \underline{a} \text {-ti }
\end{aligned}
$$

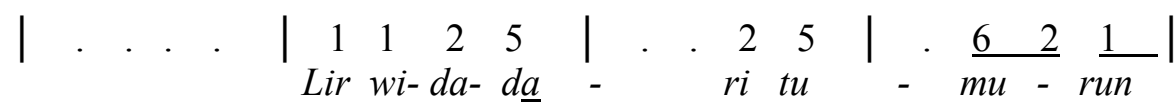

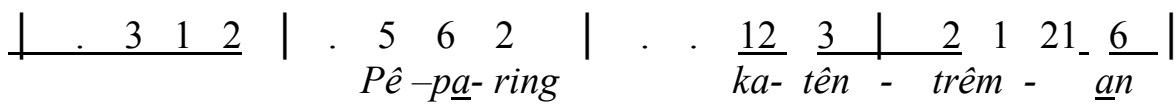

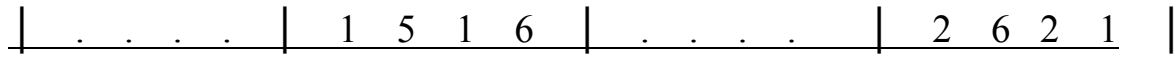

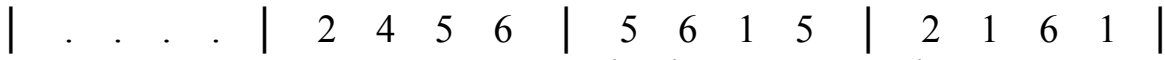

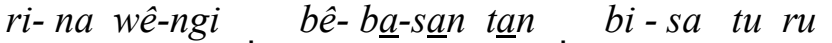

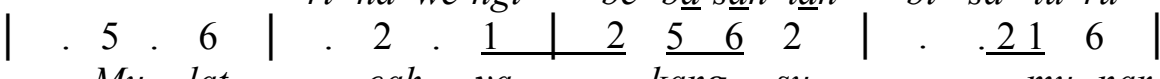

$$
\begin{aligned}
& M u \text {-lat } \quad c \underline{a} h-y a \text { kang su - } m u \text {-nar }
\end{aligned}
$$

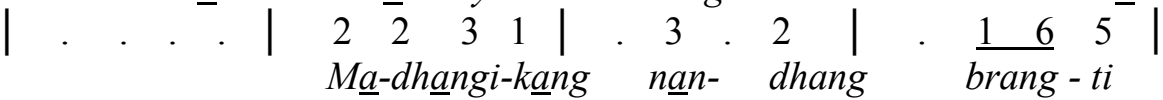

5. Gérongan dalam Lạdrang Pocung.

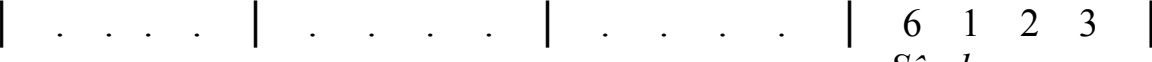

$$
\begin{aligned}
& \text { Sê- kar po-cung }
\end{aligned}
$$

${ }^{15}$ Asal.Sugiarto, 1997, 6.

${ }^{16}$ Asal.Sugiarto, 1997, 137. 


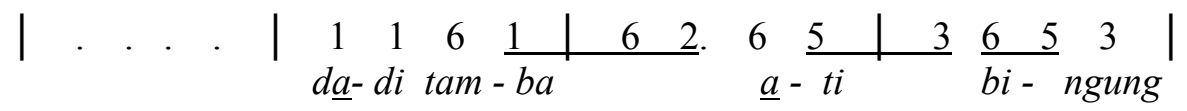

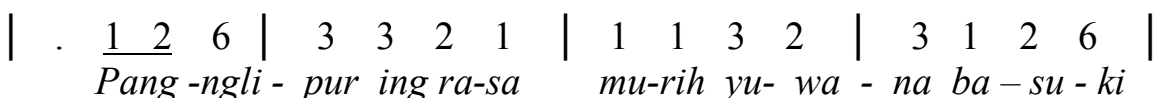

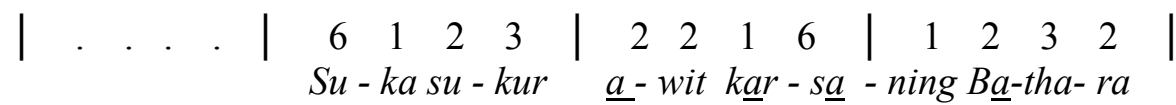

Gérongan (Irama III)

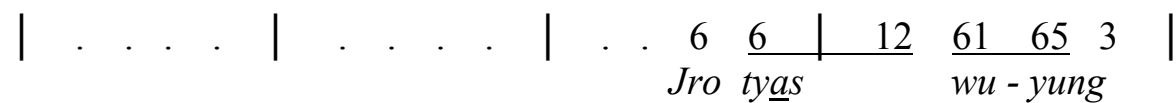

$$
\begin{aligned}
& |\cdot .+| \cdot .+\left|\cdot \frac{3}{m u-\frac{6}{l \underline{a} t}} 1\right| \frac{1}{s \hat{e}-k a r} \mid
\end{aligned}
$$

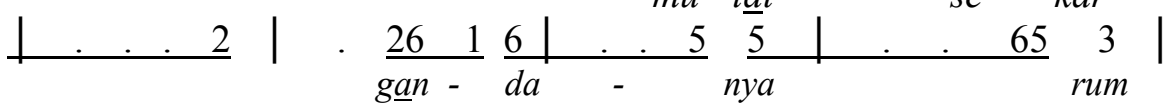

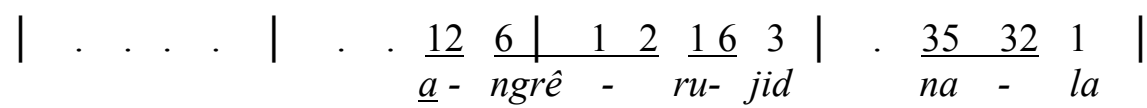

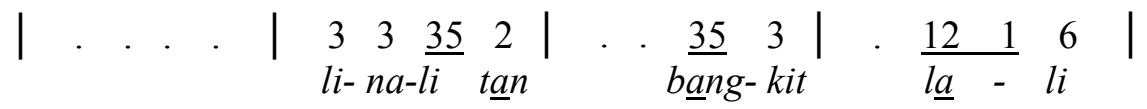

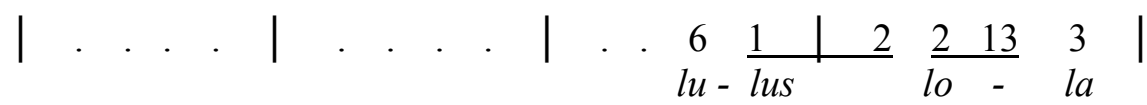

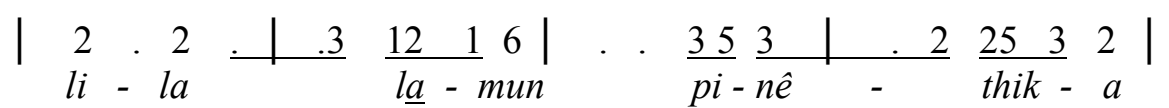

2. Hiya mathuk bakalé tansah kêpêthuk

Tinêmuné nyata

Jêbul mung angèsi-èsi

Wité dhuwur tan gampang tiniyungêna.

3. Yèn satuhu, arum njâwi lêbêtipun

Langgênga umêkar

Mangka sudarsana yêkti

Awit mulya ngambar gandaning kusuma. ${ }^{17}$

6. Gérongan Durma Ladrang Kagok. ${ }^{18}$

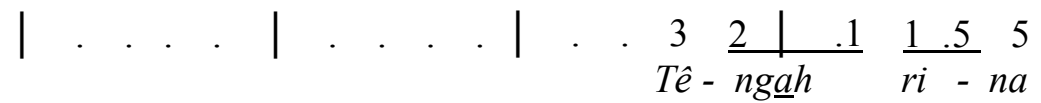

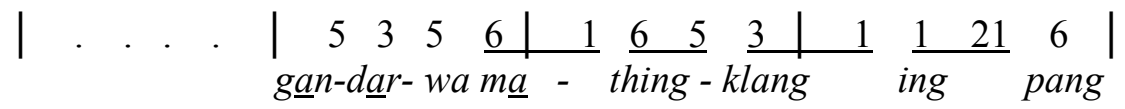

${ }_{17}^{17}$ Asal.Sugiarto, 1997, 153.

${ }^{18}$ Asal.Sugiarto, 1997, 86-87. 


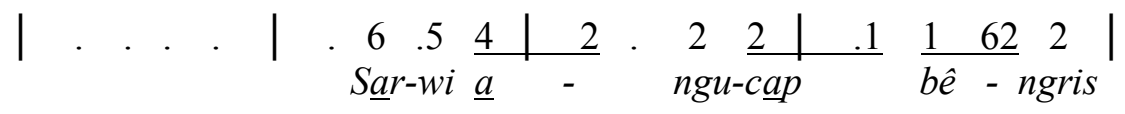

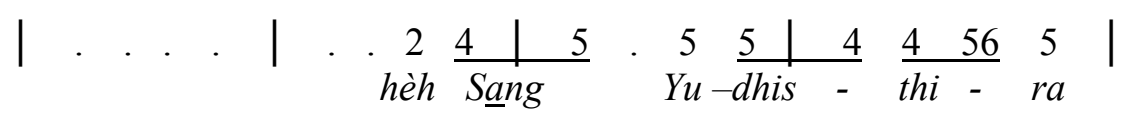

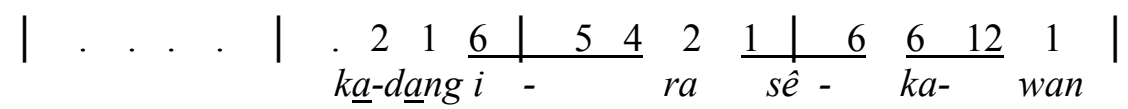

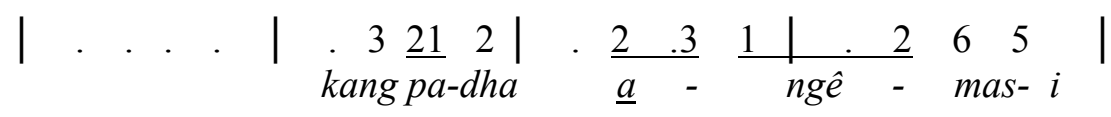

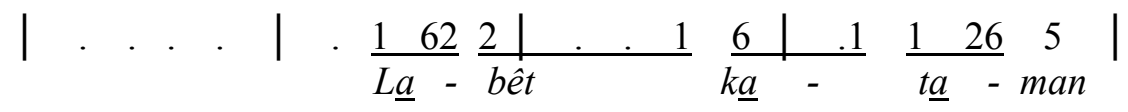

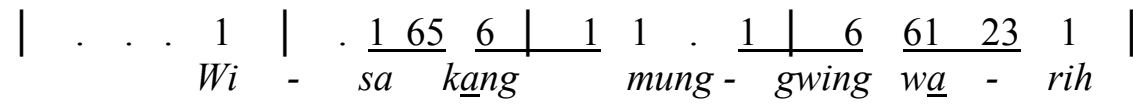

\section{Lêlagon.}

Lêlagon yang menggunakan sumber Macapat ada yaitu: (1). Lêlagon Pangkur dalam Kêtạwang Pangkur Pêgatsih, (2) Lêlagon dalam Lancaran Gámbuh Pangatag, (3) Lêlagon Lancaran Gambuh, (4) Lelagon Asmarandana dalam Lancaran Begadang. Adapun visualisasinya sebagai berikut.

1.Lêlagon Pangkur dalam Kêtawang Pangkur Pêgatsih. ${ }^{19}$

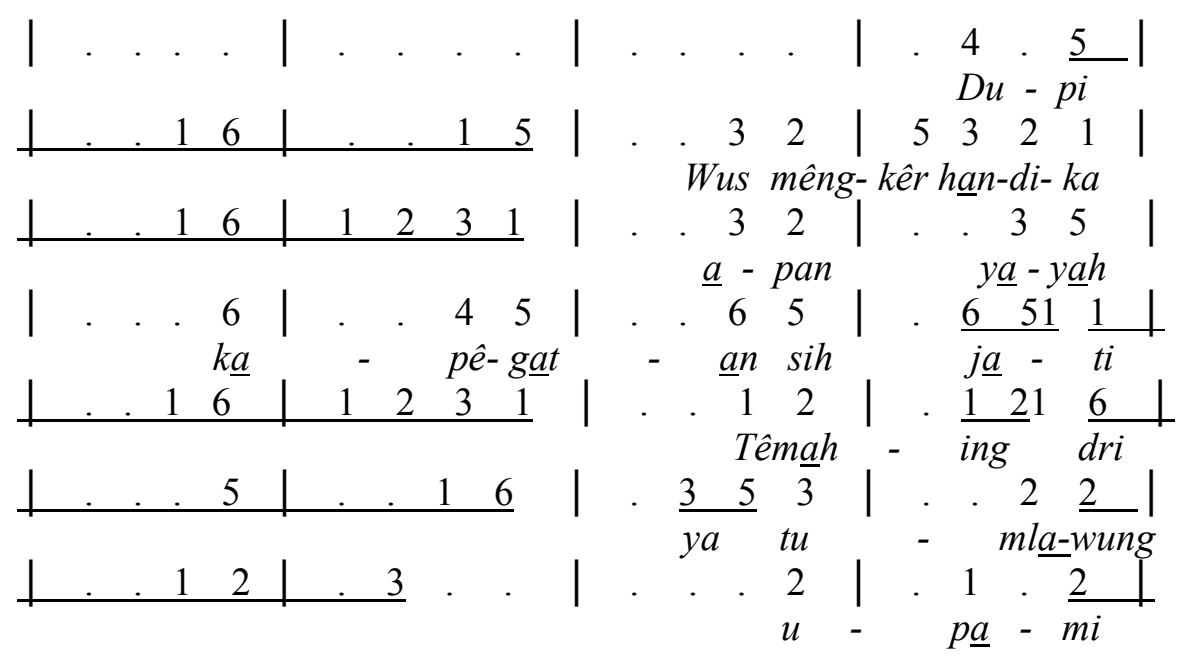

\footnotetext{
${ }^{19}$ Gatot Sasminto, 2000, 1.
} 


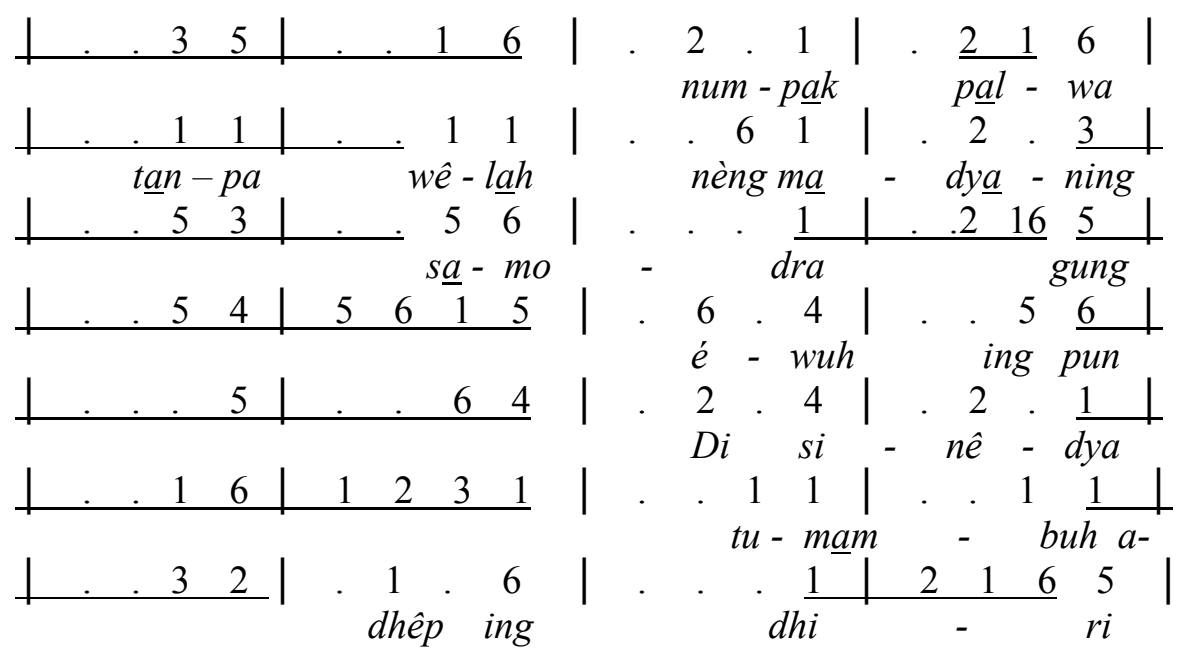

2.Lêlagon dalam Lancaran Gambuh Pangatag. ${ }^{20}$

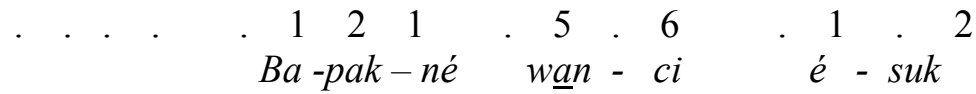

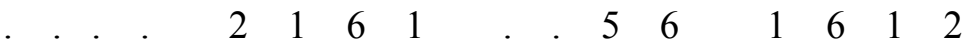

$$
\begin{aligned}
& \text { tlâtèn têmên ko-wé thê-nguk thê-nguk } \\
& \begin{array}{lllllllllllllll}
. & . & 6 & 5 & 6 & 4 & 4 & 4 & 6 & 5 & 6 & 3 & 2 & 1
\end{array} \\
& \text { ngé-ling-a-na ing pa-won kên-dhil-lé nggo-ling }
\end{aligned}
$$

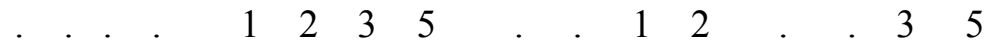

$$
\begin{aligned}
& \text { Lha } i-k u h \underline{a}-r \underline{a} k b u \text { - tuh - mu } \\
& \begin{array}{llllllllllll}
7 & 6 & 5 & 4 & . & . & 6 & 5 & 6 & \underline{3} & 2 & 1
\end{array} \\
& i-\operatorname{sèn} i-\operatorname{sèn} \quad \text { jro-ning } \quad \underline{a}-\text { won }
\end{aligned}
$$

Iya bênêr kandhamu

Pawon iku dáadi kwajibanku

Ning pikirên bêras êntèk bumbu tapis

Yèn ngono aku sing kojur

Apa sing kudu takk êdol

Aja kaladuk gêmblung

Uwong lanang mung pawitan dhêngkul

Kowè sênêng yén brayatmu pada klingsir

Mangka a ku sênêng nganggur

Mangan turu omong kosong

Hạmbok wêlas anakmu

${ }^{20}$ Gatot Sasminto, 2000, 25. 
Galo kaé ana kêbon njêmbrung

Srêgêpana olah lêmah ditanduri

Aku njaluk sangu pacul

Tumandang anggarap kêbon

\section{Lêlagon dalam Lancaran Gambuh.$^{21}$}

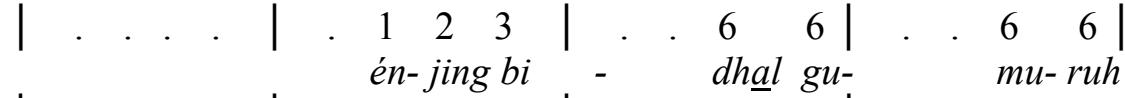

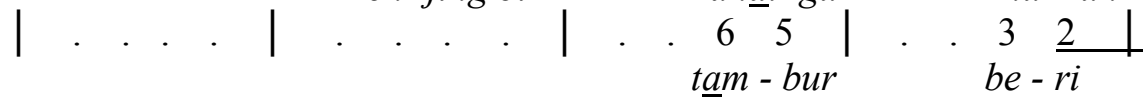

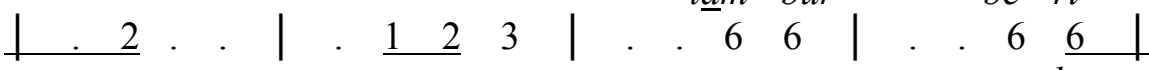

$$
\begin{aligned}
& \text { gong ma - gu-ru ngungkung }
\end{aligned}
$$

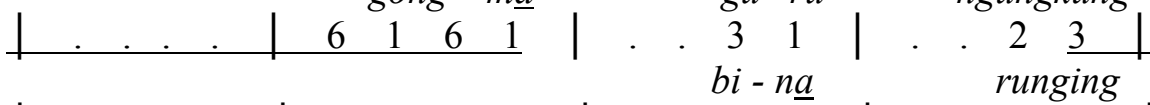

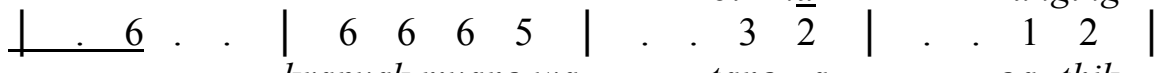

$$
\begin{aligned}
& \text { krapyak myang } w \underline{a} \text { - } \quad \text { tang } \underline{a} \text { - } g \underline{a}-\text { thik }
\end{aligned}
$$

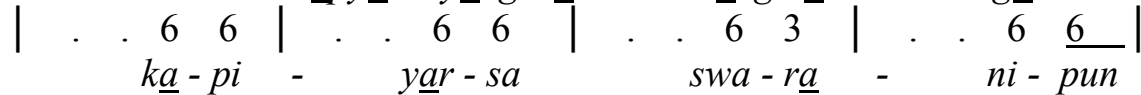

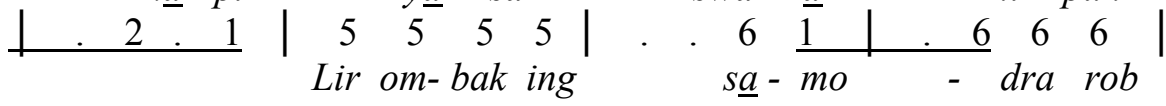

\section{Lelagon Asmarandana dalam Lancaran Wira-Wiri. ${ }^{22}$}

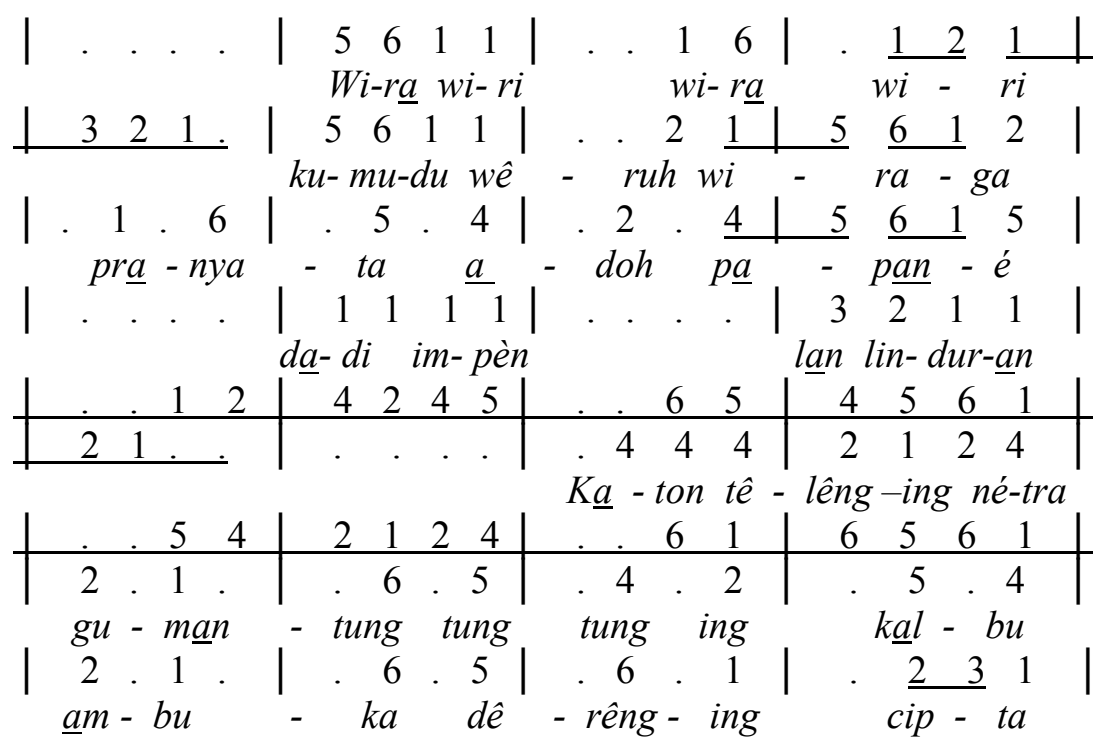

Setelah disimak berbagai gending karya Ki Nartosabdo, ditemukan sebagian gending yang menggunakan idiom Sêkar Macapat, disusun dalam bentuk bawa,

\footnotetext{
${ }^{21}$ Asal Sugiarto, 1994/1995: 39.

${ }^{22}$ Asal Sugiarto, 1994/1995: 230
} 
gérongann, dan lêlagon. Sajian Macapat tersebut ditampilkan secara eksplisit maupun implisit. Secara eksplisit diungkapkan menjadi judul gending seperti: Bawa Sêkar Mijil, bawa Sêkar Gambuh, bawa Sêkar Kinathi, bawa Sêkar Pangkur, bawa Sêkar Asmarandana, bawa Sêkar Sinom, bawa Sêkar Dhandhanggula, bawa Sêkar Pocung, Kêtawang Mijil Panglilih, Láadrang Pocung, Ladrang Asmarandana, Lancaran Gámbuh, dan Ladrang Pangkur.

Petunjuk lainnya dicantumkan kata-kata dalam gending seperti: Sêkar Macapat Kinanti yang terdapat pada Ladrang Têbu Sakuyun slendro manyura yang di dalamnya tersurat kata 'Kinanti', sama halnya memberi petunjuk bahwa gending tersebut menggunakan identitas Sêkar Macapat Kinanthi. Kata kinathi sebagai pembuka kalimat dalam gérongan sebagai berikut. ${ }^{23}$

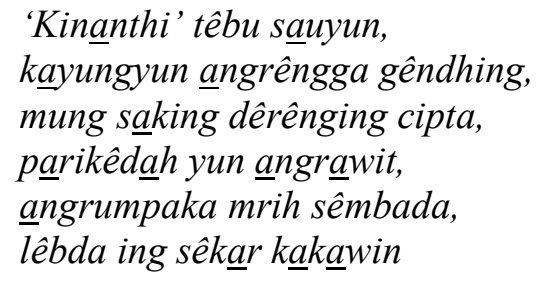

Secara implisit seperti: dalam lagu-lagu ciptaan Ki Nartosabdo seperti Asmarandana yang terkandung di dalam Ladrang Lara Asmara slendro pathet sanga. Adapun Di samping itu terdapat dua kalimat yang secara terselubung menunjukkan Sêkar Asmarandana, yaitu kalimat 'kapanduk lara asmara' dan kalimat 'Nyata gawé lara asmara'. Adapun syair lengkapnya sebagai berikut. ${ }^{24}$

Kunèng wau sang Apêkik, nênggih Bagus Pranacitra, wangsul saking adu jago, kapanduk 'lara asmara', mulat éndạhing warna, ngujiwaté Rara Mendut, dádi linduran kéwala

Untuk menentukan kriteria Macapat dari guru lagu (bunyi kata akhir setiap, guru wilangan (jumlah suku kata setiap barus), dan guru gatra (jumlah baris dalam setiap tembang). Sebagai contoh syair Sêkar Asmarandana di bawah ini mempunyai guru gatra sebanyak 7 baris atau gatra, guru wilangan 8 -i, 8-a, 8-e/o, 8-a, 7-a, 8-u, 8-a, dan guru lagu i, a, e/o, a, a, u, a.

\footnotetext{
${ }^{23}$ Asal Sugiarto, 1994/1995: 248-249.

${ }^{24}$ Asal Sugiarto, 1994/1995: 99-100.
} 
Wira-wiri wira-wiri,

kumudu wêruh wiraga,

pranyata adoh papané,

dádi impèn lan linduran,

katon têlênging nétra,

gumantung tungtunging kalbu,

Ambuka dêrênging cipta. ${ }^{25}$ (A. Sugiarto, 1994-1995: 230).

Sêkar Macapat yang terdapat pada lêlagon diungkapkan secara implisit, yaitu pada Lancaran Begadhang pelog nêm, menggunakan syair yang berpedoman pada Macapat Sinom sebagai berikut.

Yo ayo-ayo bêgadhang, lèk-lèkan têmbungé jawi, nêdhêngé wulan purnama, kêncar-kêncar anyunari, têmbangan amêmuji, dhas $\underline{a}$ r dina malêm minggu, ing wêngi kaya rina, tangga têparo nêkani, urut dạlán kèh jaka Kênya bêgadhang

\section{Penutup}

Akhirnya pada suatu kesimpulan, bahwa Ki Nartasabdo menggunakan Sêkar Macapa t sebagai salah satu sumber ide dalam penciptaan gending-gending karawitan, diungkapkan dalam elemen-elemen garap gending, yaitu: bawa, gérongan , dan lêlagon. Oleh karena dikaitkan dengan nada-nada dan suasana gending yang berbeda maka lagu dan cakêpan tidak sepenuhnya mengikuti syair dan cêngkok dalam Sêkar Macapat. Sêkar Macapat dalam gending-gending karya Ki Nartasabdo diungkapkan secara implisit dan eksplisit baik dalam bawa, gêrongan, dan lêlagon. Adapun contoh gending-gendingnya seperti: Bawa Sêkar Mijil, Ladrang Pocung, Lêlagon Gámbuh Pangatag, Lancaran Wira-wiri, dan Lancaran Bêgadhang (Sinom).

${ }^{25}$ Asal Sugiarto, 1994/1995: 230. 


\section{Kepustakaan}

Anonim, tanpa tahun, Kidungan Jangkep, Surakarta, Cendrawasih.

Kayam, Umar, 1981, Seni Tradisi Masyarakat, PT. Sinar Harapan, Jakarta.

Herusatoto, Budiono, 1983, Simbolisme dalam Budaya, PT, Hindita, Yogyakarta.

Marsudi, 1998, "Ciri Khas Gendhing-gendhing Ki Nartosabdo Suatu Kajian Aspek Musikologi Karawitan “ Tesis S-2 Program Pasca Sarjana, Universitas Gadjah Mada Yogyakarta.

Purwadi, 1995, Sekar Mekar, CV. Cenderawasih, Surakarta.

Sasminto, Gatot., 1994. Kumpulan Gêndhing-Gêndhing Lan Lagon Dolanan Ki Nartosabdo, Jilid I, II,III. CV. Cenderawasih, Surakarta.

Siswo Pamucalan Sekar, tt Diktat "Kumpulan Sekar-Sekar", Kawedanan Hageng Punokawan Kridhomardawa.

Soekanto, Soejono. Tallcott Parsons Fungsionalisme Imperatif, CV. Rajawali, Jakarta.

Soetarno, 2005. Pertunjukan Wayang \& Makna Simbolisme, STSI Press. Surakarta.

Subalidinata, R.S, 1994, Kawruh Kasustraan Jawa, Yayasan Pustaka Nusantara, Yogyakarta.

Sugiarto, A, 1996/1997. "Kumpulan Gendhing Jawa Karya Ki Nartosabdo, Proyek Pengembangan Seni Budaya Daerah Jawa Tengah, Pemerintah Propinsi Dati I Jawa Tengah, Semarang.

Waridi, 2006. Karawitan Wayang Kulit Purwa Gaya Surakarta, Senawangi, Surakarta. 